\title{
RECOVERY AND UTILIZATION OF COALMINE METHANE: PILOT-SCALE DEMONSTRATION PHASE
}

\section{FINAL REPORT}

Reporting Period Start Date: October 1, 2000

Reporting Period End Date: April 30, 2004

\section{Prepared by:}

George Steinfeld, Project Manager

Jennifer Hunt, Lead Project Engineer

September 28, 2004

\section{Contract DE-FC26-00NT40979}

FuelCell Energy, Inc.

3 Great Pasture Road

Danbury, CT 06813 


\section{DISCLAIMER}

This report was prepared as an account of work sponsored by an agency of the United States Government. Neither the United States Government nor any agency thereof, nor any of their employees, makes any warranty, express or implied, or assumes any legal liability or responsibility for the accuracy, completeness, or usefulness of any information, apparatus, product, or process disclosed, or represents that its use would not infringe privately owned rights. Reference herein to any specific commercial product, process, or service by trade name, trademark, manufacturer, or otherwise does not necessarily constitute or imply its endorsement, recommendation, or favoring by the United States Government or any agency thereof. The views and opinions of authors expressed herein do not necessarily state or reflect those of the United States Government or any agency thereof. 


\begin{abstract}
A fuel cell demonstration was conducted on coalmine methane to demonstrate the utilization of methane emissions associated with underground coal mining operations in a carbonate Direct FuelCell $^{\circledR}\left(\mathrm{DFC}^{\circledR}\right)$ power plant. FuelCell Energy (FCE) conducted the demonstration with support from the U.S. Department of Energy (DOE) National Energy Technology Laboratory (NETL) and in cooperation with Northwest Fuel Development, the operator of the Rose Valley test site in Hopedale, Ohio.

The fuel cell power plant, a first generation sub megawatt power plant, was operated on CMM between August 1, 2003 and December 13, 2003. The direct fuel cell operated on low-Btu CMM with $42 \%$ methane content and achieved performance levels comparable to natural gas on a Btu feed basis. During this period 1456 hours on-load operation was achieved. The total power generated using CMM was 134 megawatt-hours (MWh) of electricity. The power generated was connected to the American Electric Power grid by a 69-kilovolt $(\mathrm{kV})$ transformer. The maximum power level achieved was $140 \mathrm{~kW}$. Efficiency of power generation was $40 \%$ based on the lower heating value (LHV) of the CMM. Compression and drying of the CMM resulted in additional parasitic load, which reduced the overall efficiency to $36 \% \mathrm{LHV}$. In future applications, on-board compression and utilization of the saturated CMM without drying will be investigated in order to reduce the auxiliary power requirements. By comparison, the internal combustion engines operating on CMM at the Hopedale site operate at an over efficiency of $20 \%$. The over-all efficiency for the fuel cell is therefore $80 \%$ higher than the internal combustion engine (36\% vs. $20 \%)$.
\end{abstract}

Future operation of a $250 \mathrm{~kW}$ Fuel Cell Power Plant on CMM will utilize 18,400,000 cubic feet of methane per year. This will be equivalent to: a) avoiding 7428 metric tons of $\mathrm{CO}_{2}$ emissions, b) avoiding 16.4 million pounds of $\mathrm{CO}_{2}$ emissions, c) removing 1640 cars off the road for one year, d) heating 267 households for 1 year, d) planting 2234 acres of trees. (Reference: U.S. Environmental Protection Agency, Coalbed Methane Outreach Program, http://www.epa.gov/coalbed/resources/converter.html)

Based on the results obtained in this demonstration it can be concluded that utilization of fuel cells to mitigate CMM emissions is an attractive option that can be utilized to generate power at high efficiencies and with very low emissions. 


\section{TABLE OF CONTENTS}

$\underline{\text { Page }}$

Abstract

i

Table of Contents

List of Figures

List of Tables

Introduction

iv

Executive Summary

$\begin{array}{ll}\text { Experimental } & 10\end{array}$

$\begin{array}{ll}\text { A. Design and Construction } & 10\end{array}$

1. Fuel Cell Power Plant Description 10

a) Fuel Cell Module 11

b) BOP 12

c) $\mathrm{EBOP} \quad 12$

2. Site Preparation 14

a) Coal Mine Methane Gas Quality 15

b) Gas Compressor 16

c) Gas Dryer 16

d) Transformer 18

e) Water Supply System 19

f) Foundation for the Fuel Cell Power Plant 20

g) Emissions Permitting 20

B. Power Plant Installation 20

$\begin{array}{ll}\text { Results and Discussion } & 22\end{array}$

A. Fuel Cell Power Plant Performance on Coal Mine Methane 23

1. Power Level 23

2. Power Plant Efficiency 23

3. Stable Operation on Coal Mine Methane 24

4. Comparison to Natural Gas Operations 24

5. Environmental Impact 25

6. Power Plant Availability 27

$\begin{array}{ll}\text { Conclusions } & 28\end{array}$

References $\quad 29$

$\begin{array}{ll}\text { List of Acronyms } & 31\end{array}$ 


\section{LIST OF FIGURES}

$\underline{\text { Page }}$

1 Effectiveness of Various Technologies in Utilizing Coal Mine Methane

2 Submegawatt Fuel Cell Power Plant

$3 \quad$ Submegawatt Fuel Cell Module Used for CMM Testing

$4 \quad$ Simplified Process Flow Diagram

5 Rose Valley Coal Mine Methane Test Site in Hopedale, Ohio

6 Plot Plan of the Rose Valley Coal Mine Methane Test Site in Hopedale, OH

$7 \quad$ Process Flow Diagram for Coal Mine Methane Compressor

8 Coal Mine Methane Compressor at the Rose Valley Test Site

9 Gas Dryer Installed at Rose Valley for Coal Mine Methane

$1069 \mathrm{kV}$ Transformer at the Rose Valley Site used for Connecting Fuel Cell Power to the AEP Grid

11 Schematic of Water Supply System at the Rose Valley Test Site

12 Well Water and Spring Tank Controls. Spring Tank Pump Control in Back

13 The Fuel Cell Power Plant Arriving at the Hopedale, Ohio Site

14 Unloading of the Fuel Cell Power Plant at the Rose Valley Test Site in Hopedale, Ohio

15 Fuel Cell Power Plant Installed and Connected to Utilities at Site

16 Cumulative Power Output on Coal Mine Methane

17 DC Stack Voltage Showing Stable Operation on Coal Mine Methane

18 Comparison of Power Output for Coal Mine Methane Operation vs.

Natural Gas Operation

19 Down Time Breakdown for the Fuel Cell Demonstration on 


\section{LIST OF TABLES}

$\underline{\text { Page }}$

1. U.S. Sources of $\mathrm{CH}_{4}$ Emissions 1

$2 \quad$ Total U.S. Coal Mining Methane Emissions (Billions Cubic Feet) 1

$3 \quad$ Underground Coal Mining Methane Emissions (Billion Cubic Feet) 2

$4 \quad$ Total Coal Mining Methane Emissions by State (Millions of Cubic Feet) 3

$5 \quad$ Comparison of Emissions from Power Generation Alternatives 4

ES-1 Carbonate Fuel Cell Power Plant (HM-4R) Operations on Coal Mine Methane 8

$6 \quad$ Submegawatt Fuel Cell Module Used for Coal Mine Methane Testing 11

$7 \quad$ Water Quality Requirements for Fuel Cell Plant Operation 13

8 Gas Analysis of Coal Mine Methane at the Rose Valley Test Site 16

9 Trace Contaminant Level in Coal Mine Methane 16

10 Spring Water Quality at Rose Valley Test Site 19

11 Carbonate Fuel Cell Power Plant Operations on Coal Mine Methane 22

12. Carbon Dioxide Emissions of a Direct Fuel Cell Power Plant 26

13 Environmental Impact a Fuel Cell Power Plant 26 


\section{INTRODUCTION}

Coalmines are the fourth largest source of U.S. methane emissions to the atmosphere, emitting 150 billion cubic feet per year $^{1}$ in 2001 . The impact of this methane emission on global warming in terms of $\mathrm{CO}_{2}$ equivalent units is shown in Table 1.

Table 1. U.S. SOURCES OF $\mathrm{CH}_{4}$ EMISSIONS $\left(10^{12}\right.$ GRAMS CO $_{2}$ EQUIVALENT) ${ }^{(1)}$ : Methane emissions from coal mining is fourth largest source of methane emissions to the atmosphere

\begin{tabular}{|c|c|c|c|c|c|c|c|c|}
\hline Source & 1990 & 1995 & 1996 & 1997 & 1998 & 1999 & 2000 & 2001 \\
\hline Landfills & 212.1 & 216.1 & 212.1 & 207.5 & 202.4 & 203.7 & 205.8 & 202.9 \\
\hline Natural Gas Systems & 122.0 & 127.2 & 127.4 & 126.0 & 124.0 & 120.3 & 121.2 & 117.3 \\
\hline Enteric Fermentation & 117.9 & 123.0 & 120.5 & 118.3 & 116.7 & 116.6 & 115.7 & 114.8 \\
\hline Coal Mining & 87.1 & 73.5 & 68.4 & 68.1 & 67.9 & 63.7 & 60.9 & 60.7 \\
\hline Manure Management & 31.3 & 36.2 & 34.9 & 36.6 & 39.0 & 38.9 & 38.2 & 38.9 \\
\hline Wastewater Treatment & 24.1 & 26.6 & 26.8 & 27.3 & 27.7 & 28.2 & 28.3 & 28.3 \\
\hline Petroleum Systems & 27.5 & 24.2 & 23.9 & 23.6 & 22.9 & 21.6 & 21.2 & 21.2 \\
\hline Rice Cultivation & 7.1 & 7.6 & 7.0 & 7.5 & 7.9 & 8.3 & 7.5 & 7.6 \\
\hline Stationary Sources & 8.1 & 8.5 & 8.7 & 7.5 & 7.2 & 7.4 & 7.6 & 7.4 \\
\hline Mobile Sources & 5.0 & 4.9 & 4.8 & 4.7 & 4.6 & 4.5 & 4.4 & 4.3 \\
\hline Petrochemical Production & 1.2 & 1.5 & 1.6 & 1.6 & 1.6 & 1.7 & 1.7 & 1.5 \\
\hline $\begin{array}{l}\text { Field Burning of Agricultural } \\
\text { Residues }\end{array}$ & 0.7 & 0.7 & 0.7 & 0.8 & 0.8 & 0.8 & 0.8 & 0.8 \\
\hline Silicon Carbide Production & + & + & + & + & + & + & + & + \\
\hline International Bunker Fuels* & 0.2 & 0.1 & 0.1 & 0.1 & 0.1 & 0.1 & 0.1 & 0.1 \\
\hline Total* & 644.0 & 650.0 & 636.8 & 629.5 & 622.7 & 615.5 & 613.4 & 605.9 \\
\hline \multicolumn{9}{|c|}{+ Does not exceed 0.05 teragram $\mathrm{CO}_{2} \mathrm{Eq}}$. \\
\hline \multicolumn{9}{|c|}{ * Emissions from International Bunker Fuels are not included in totals. } \\
\hline
\end{tabular}

The recoverable portions of these emissions are the underground mining, and post underground mining emissions which totaled 124 billion cubic feet in 2001 as shown in Table 2.

\section{Table 2. TOTAL U.S. COAL MINING METHANE EMISSIONS} (BILLIONS CUBIC FEET):

151 billion cubic feet methane emissions in 2001 of which 124 billion is recoverable

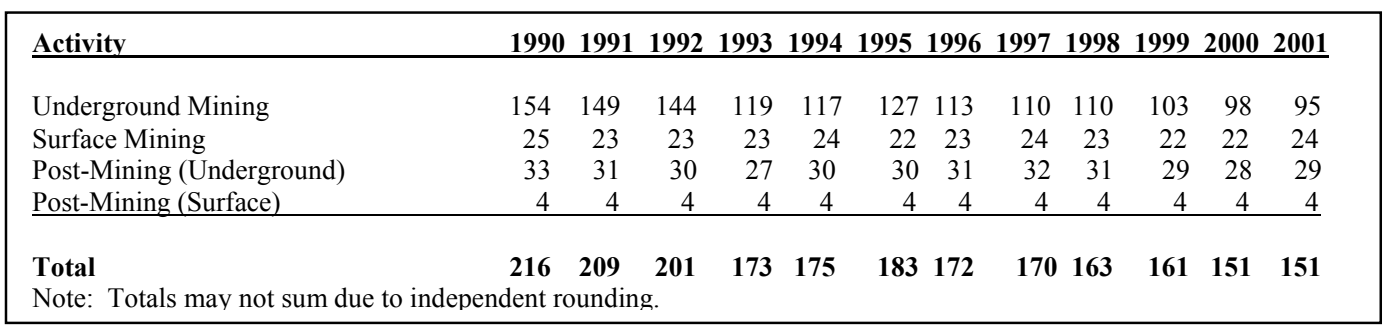

The underground mining emissions of 95 billion cubic feet in 2001 are net of total liberated and recovered for use as shown in Table 3. About $62 \%$ of the methane emissions are in the form of ventilation output. This means that the methane is removed in very dilute form with the mine 
ventilation air. The amount remaining in 2001 after subtracting ventilation output (84 billion cubic feet), and already recovered coal mine methane (40 billion cubic feet) is 11 billion cubic feet of useable coal mine methane. This is equivalent to $598 \mathrm{MW}$ of fuel cell power for the year 2001.

\section{Table 3. UNDERGROUND COAL MINING METHANE EMISSIONS} (BILLION CUBIC FEET):

The 11 billion cubic feet of useable and unrecovered CMM in 2001

\begin{tabular}{|c|c|c|c|c|c|c|c|c|c|c|c|c|}
\hline Activity & 1990 & 1991 & 1992 & 1993 & 1994 & 1995 & 1996 & 1997 & 1998 & 1999 & 2000 & 2001 \\
\hline Ventilation Output & 112 & NA & NA & 95 & 96 & 102 & 90 & 96 & 94 & 92 & 87 & 84 \\
\hline Degasification System Liberated & 54 & NA & NA & 45 & 46 & 46 & 50 & 42 & 49 & 41 & 45 & 48 \\
\hline Total Underground Liberated & 167 & 164 & 162 & 142 & 144 & 157 & 149 & 138 & 146 & 135 & 134 & 135 \\
\hline Recovered \& Used & (14) & (15) & (17) & (23) & (27) & $(30)$ & $(36)$ & (28) & (35) & $(32)$ & $(36)$ & (40) \\
\hline Total & 154 & 149 & 144 & 119 & 117 & 127 & 113 & 110 & 110 & 103 & 98 & 95 \\
\hline
\end{tabular}

Table 4 shows the total U.S. coalmine methane emissions by state. West Virginia, Alabama, Pennsylvania, Kentucky and Colorado are the top five methane-emitting states. Although a 30\% reduction in coal mine methane emission was observed between 1990 and 2001 due to less mining of gassy coal from underground mines and increased use of methane collected by degasification systems, the U.S. coal mine methane emissions remain significant.

According to the Intergovernmental Panel on Climate Change (IPCC), methane is 23 times more effective as $\mathrm{CO}_{2}$ at trapping heat in the atmosphere based on the Global Warming Potential (GWP) over a 100-year time frame. Over the last 250 years, the concentration of methane in the atmosphere increased by $150 \%$ (IPCC 2001). Experts believe that over half of the atmospheric increase was due to emissions from anthropogenic (man-made) sources such as landfills, natural gas and petroleum systems, agricultural activities, coal mining, stationary and mobile combustion, wastewater treatment and certain industrial processes ${ }^{(1)}$.

The recovery and utilization of coalmine methane is therefore important in order to minimize methane emissions to the atmosphere and the associated global warming. Utilization of coalmine methane can be achieved in a number of ways. When the coalmine methane is of sufficient quality (i.e. $95 \%$ methane or greater), it can be compressed for pipeline gas. When coalmine methane is below the quality required for pipeline gas, use for power generation is another option. Figure 1 below, shows the effectiveness of utilizing coalmine methane for power generation using various technologies.

Carbonate fuel cells are the most efficient technology for utilizing coalmine methane and can also operate on dilute fuel gas such as low quality coalmine methane. In addition, carbonate fuel cells also have the lowest air emissions of the available technologies as shown in Table 5. 


\section{Table 4. TOTAL COAL U.S. MINING METHANE EMISSIONS BY STATE (MILLIONS OF CUBIC FEET) ${ }^{(1)}$ :}

West Virginia, Alabama, Pennsylvania are top three CMM producers

\begin{tabular}{|c|c|c|c|c|c|c|c|c|c|c|}
\hline State & 1990 & 1993 & 1994 & 1995 & 1996 & 1997 & 1998 & 1999 & 2000 & 2001 \\
\hline Alabama & 33,175 & 26,694 & 30,283 & 39,334 & 29,928 & 26,440 & 27,058 & 26,209 & 24,078 & 22,648 \\
\hline Alaska & 13 & 12 & 12 & 13 & 11 & 11 & 10 & 12 & 12 & 11 \\
\hline Arizona & 402 & 433 & 464 & 425 & 371 & 417 & 403 & 419 & 466 & 477 \\
\hline Arkansas & 0 & 0 & 0 & 0 & 0 & 0 & 0 & 0 & 0 & 0 \\
\hline California & 2 & - & - & - & - & - & 0 & 0 & 0 & 0 \\
\hline Colorado & 10,117 & 7,038 & 9,029 & 8,541 & 5,795 & 9,057 & 9,057 & 9,296 & 10,677 & 10,935 \\
\hline Illinois & 10,643 & 8,737 & 10,624 & 11,106 & 10,890 & 8,571 & 7,859 & 7,812 & 8,531 & 7,267 \\
\hline Indiana & 3,149 & 2,623 & 2,791 & 2,106 & 2,480 & 3,088 & 3,239 & 2,980 & 2,492 & 3,679 \\
\hline Iowa & 3 & 1 & 0 & - & - & - & 0 & 0 & 0 & 0 \\
\hline Kansas & 5 & 3 & 2 & 2 & 2 & 3 & 3 & 3 & 1 & 1 \\
\hline Kentucky & 21,229 & 19,823 & 21,037 & 19,103 & 18,292 & 20,089 & 19,240 & 18,255 & 16,910 & 17,524 \\
\hline Louisiana & 24 & 23 & 26 & 28 & 24 & 26 & 24 & 22 & 27 & 28 \\
\hline Maryland & 510 & 245 & 256 & 259 & 287 & 296 & 282 & 260 & 345 & 341 \\
\hline Mississippi & - & - & - & - & - & - & 0 & 2 & 92 & 69 \\
\hline Missouri & 20 & 5 & 6 & 4 & 5 & 3 & 3 & 3 & 3 & 3 \\
\hline Montana & 280 & 267 & 310 & 294 & 283 & 305 & 319 & 306 & 285 & 291 \\
\hline New Mexico & 905 & 1,186 & 1,223 & 980 & 856 & 961 & 1,026 & 1,042 & 972 & 1,195 \\
\hline North Dakota & 217 & 238 & 240 & 224 & 222 & 220 & 223 & 232 & 233 & 227 \\
\hline Ohio & 4,710 & 4,110 & 4,377 & 3,900 & 3,992 & 4,313 & 4,244 & 3,820 & 3,443 & 3,462 \\
\hline Oklahoma & 13 & 14 & 52 & 14 & 14 & 132 & 137 & 209 & 208 & 366 \\
\hline Pennsylvania & 22,573 & 26,437 & 24,026 & 27,086 & 26,567 & 30,339 & 29,853 & 24,088 & 25,208 & 22,575 \\
\hline Tennessee & 800 & 350 & 338 & 366 & 418 & 390 & 309 & 349 & 306 & 372 \\
\hline Texas & 415 & 406 & 389 & 392 & 410 & 397 & 391 & 395 & 361 & 335 \\
\hline Utah & 4,562 & 4,512 & 3,696 & 3,541 & 4,061 & 4,807 & 5,060 & 4,851 & 4,045 & 3,389 \\
\hline Virginia & 45,883 & 30,457 & 26,765 & 19,893 & 19,847 & 16,972 & 14,087 & 13,539 & 12,179 & 11,621 \\
\hline Washington & 37 & 35 & 36 & 36 & 34 & 33 & 35 & 31 & 32 & 34 \\
\hline West Virginia & 55,280 & 37,803 & 36,854 & 42,992 & 42,870 & 40,197 & 43,511 & 41,500 & 37,507 & 41,464 \\
\hline Wyoming & 1,382 & 1,578 & 1,782 & 1,977 & 2,090 & 2,122 & 2,351 & 2,520 & 2,533 & 2,743 \\
\hline Total & 216,350 & 173,029 & 174,622 & 182,616 & 169,750 & 169,190 & 168,725 & 158,153 & 150,945 & 150,860 \\
\hline
\end{tabular}

+ Does not exceed 0.5 Million Cubic Feet

Note: The emission estimates provided above are inclusive of emissions from underground mines, surface mines and post-mining activities. The following states have neither underground nor surface mining and thus report no emissions as a result of coal mining: Connecticut, Delaware, Florida, Georgia, Hawaii, Idaho, Maine, Massachusetts, Michigan, Minnesota, Nebraska, Nevada,

New Hampshire, New Jersey, New York, North Carolina, Oregon, Rhode Island, South Carolina,

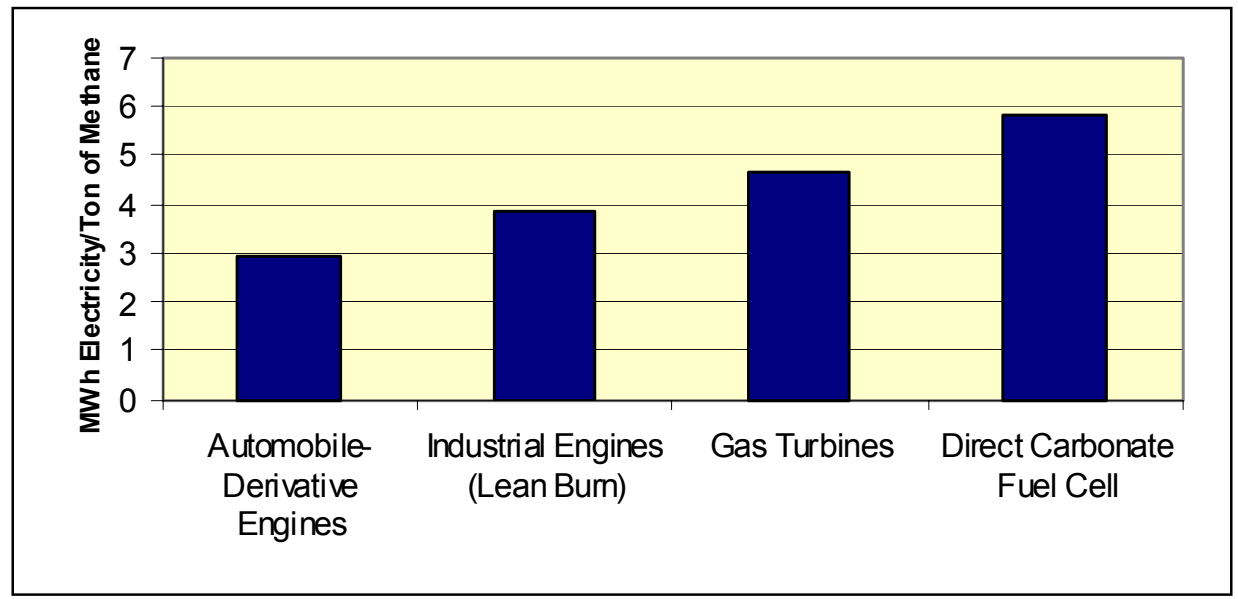

Figure 1. EFFECTIVENESS OF VARIOUS TECHNOLOGIES IN UTILIZING COALMINE METHANE:

The Direct Carbonate Fuel Cell utilizes CMM more efficiently 
Table 5. COMPARISON OF EMISSIONS FROM POWER GENERATION ALTERNATIVES:

Fuel cell emissions are significantly below other power generation technologies

\begin{tabular}{|c|c|c|c|c|c|}
\hline & $\begin{array}{c}\text { Performance } \\
\text { Efficiency, \% } \\
\text { LHV }\end{array}$ & $\begin{array}{c}\mathrm{CO} \\
\mathrm{Lbs} / \mathrm{MWh}\end{array}$ & $\begin{array}{c}\mathrm{NO}_{\mathrm{x}} \\
\mathrm{Lbs} / \mathrm{MWh}\end{array}$ & $\begin{array}{c}\mathrm{SO}_{\mathrm{x}} \\
\mathrm{Lbs} / \mathrm{MWh}\end{array}$ & $\begin{array}{c}\mathrm{CO}_{2} \\
\mathrm{Lbs} / \mathrm{MWh}\end{array}$ \\
\hline $\begin{array}{l}\text { Internal Combustion } \\
\text { Reciprocating Engines }\end{array}$ & & & & & \\
\hline $\begin{array}{r}\text { Automobile - Derivative } \\
\text { Engines }\end{array}$ & $26-31$ & $3-6$ & $12-71$ & & 1852 \\
\hline $\begin{array}{r}\text { Industrial Engines } \\
\text { (Lean Burn) }\end{array}$ & $31-34$ & 7.4 & 4.4 & 0.01 & 1431 \\
\hline Gas Turbines & 40 & 3 & 12 & 0.011 & 1181 \\
\hline $\begin{array}{c}\text { Direct Carbonate } \\
\text { Fuel Cell }\end{array}$ & $45-50$ & 0.006 & 0.004 & 0.003 & 945 \\
\hline
\end{tabular}

\section{A. $\quad \underline{\text { Objective }}$}

The objective of this project was to demonstrate the utilization of methane emissions associated with underground coal mining operations in a FuelCell Energy carbonate Direct FuelCell ${ }^{\circledR}$ $\left(\mathrm{DFC}^{\circledR}\right)$ power plant.

\section{B. Summary of Prior Phases of the Program}

DOE initiated a 3-phase program to address the utilization of coalmine methane. Prior to the demonstration phase, subject of this report, the following two phases were conducted ${ }^{(2)}$.

- Phase 1 - Feasibility Study (1995)- The availability and quality of coalmine methane at the Cadiz, Ohio site was assessed in cooperation with Northwest Fuel Development and Harrison Mining Corporation (Now owned by AEP Ohio Coal LLC). This site is known as Nelms No. 1 mine at Harrison County, Ohio. This study established that the mine vent gas at the Harrison Mining, Cadiz Ohio site is acceptable for power generation using a direct carbonate fuel cell. The free flow of gas at Nelms \#5 was 300-500 MCFD, which could support 1.6 - 2.7 MW of fuel cell power. Northwest Fuel was operating several automotive internal combustion engines generating $240 \mathrm{~kW}$ at the site. The power generated was used by Harrison Mining Corporation to operate mine equipment. The mine had a base load demand of $1 \mathrm{MW}$ with an additional $1 \mathrm{MW}$ of peak demand.

Sufficient water was available at the site to meet the requirements of the fuel cell demonstration. Contaminants in the coalmine methane appeared to be minimal based on preliminary analysis during phase I. The hydrogen sulfide concentration was $0.5 \mathrm{ppm}$, $\mathrm{HCl}<.2 \mathrm{ppm}$ and $\mathrm{Cl}_{2}$ at $<0.05 \mathrm{ppm}$. Based on these results the required cleanup is similar to the cleanup system for pipeline natural gas used in fuel cell applications. 
However, the oxygen content of $0.1 \%$ would require additional processing to eliminate the oxygen.

Taking into account the above factors, a logical size range for the proposed follow-on demonstration was deemed to be $30-300 \mathrm{~kW}$.

\section{- Phase 2 Conceptual Design and Cost Estimate (1999)}

The conceptual design effort was designed to provide sufficient information to select the approach for demonstrating a carbonate fuel cell on coalmine methane. This included the following activities:

1. Determine appropriate power plant size for the demonstration

Several options were considered ranging from a $20-100 \mathrm{~kW}$ fuel cell stack, a $250 \mathrm{~kW}$ packaged power plant, or a $1.2 \mathrm{MW}$ power plant. The factors considered were cost and potential for commercial application. It was concluded that a packaged $250 \mathrm{~kW}$ power plant would be the most attractive option. This was ultimately proposed to DOE and was the size demonstrated.

\section{Evaluate options for supplying water to the fuel cell}

The source of water required for the operation of the fuel cell power plant was studied. Options included trucking water in, drilling a water well, installing water recovery capability in the fuel cell power plant, and using pond water and piping to the fuel cell. The selected approach was drilling a water well.

3. Determine quality, quantity and variability of available gas

Tests were conducted on both Phase I and Phase II to address the quality and quantity of the coalmine methane gas available at Vent \#5. Quality was quantified in Phase I in terms of gas composition and trace contaminants. Quantity was quantified in terms of gas reserves and flow rate. It was determined that adequate coalmine methane was available for the proposed fuel cell demonstration while supplying the existing engines at the site. Variability of the coalmine methane flow rate was also noted. The data studied indicated that flow rate varies inversely with barometric pressure. As barometric pressure decreased below 28.7 inches of mercury, the flow rate increases. Above 28.7 in $\mathrm{Hg}$, the flow rate reverses. Flow reversal can and does occur by leakages of ambient air into the mine. These flow reversals contribute to the oxygen content of the gas.

4. Determine gas cleanup requirements

Gas cleanup requirements covered sulfur, chlorine and oxygen removal. Sulfur and chlorides need to be lowered to $0.1 \mathrm{ppm}$. Oxygen must be lowered to $<0.2 \%$.

5. Evaluate the possibility of using power produced by the fuel cell demonstration to meet mine needs. 
The load profile at the Harrison Mining Cadiz portal indicated a daily variation in load between $320 \mathrm{~kW}$ and approximately $2 \mathrm{MW}$. A fuel cell demonstration sized at 30-250 $\mathrm{kW}$ could be utilized to meet part of this requirement. Power from the existing generator sets totaling $440 \mathrm{~kW}$ could supplement the fuel cell. The local grid would supply the balance of the power needed.

6. Evaluate the feasibility of utilizing the commercial natural gas carbonate fuel cell plant design for coal mine methane application

The feasibility of utilizing the commercial natural gas carbonate fuel cell plant design for coalmine methane application indicated that this was quite feasible. This in fact was the approach taken during the demonstration. However some modifications were necessary to add oxygen removal capability and to increase the design flow rate for the lower Btu coalmine methane gas.

- Phase 3 Demonstration (2000-2004): When the demonstration phase began, it became clear that the originally planned test site in Cadiz, Ohio did not have sufficient space for the fuel cell power plant due to additional installations made by Northwest Fuel. A nearby site in Hopedale, Ohio, also operated by Northwest Fuel was therefore made available instead. This test site was prepared for fuel cell installation by installing a concrete foundation for the fuel cell power plant, a coal mine methane compressor and dryer, a coal mine methane gas feed line, a water supply system, and a tank to store brine used in regenerating the water treatment system. In addition, a permit was obtained for the water discharge from the water treatment system while it was determined that an air emission permit was not required. The coalmine methane was analyzed prior to installation of the fuel cell and contained 42\% Methane with a heating value of 393 $\mathrm{Btu} / \mathrm{ft}^{3}$. Oxygen in the coalmine methane was analyzed at $0.05 \%$, and was less than expected. Moisture content was at saturation, which generally was not an issue except during very cold weather when freeze-up could occur. The methane content measured prior to the installation of the fuel cell power plant in 2003 was significantly lower than the $68 \%$ methane content measured in 2000 . It is believed that this was caused by drawdown of the gas supply in place and air infiltration over time. While this was a significant reduction in methane concentration compared to the expected concentration, it was felt that testing on this low quality coal mine methane would be useful in characterizing performance for gas of this quality, and would be a more stringent test demonstrating fuel cell operations achievable in a broader coal mine methane market. Higher quality gas, where available, would be expected to provide equal or better performance. 


\section{EXECUTIVE SUMMARY}

The objective of this project was to demonstrate the utilization of methane emissions associated with underground coal mining operations in a carbonate Direct FuelCell ${ }^{\circledR}\left(\mathrm{DFC}^{\circledR}\right)$ power plant. FuelCell Energy (FCE) conducted the demonstration with support from Northwest Fuel Development, the operator of the Rose Valley test site in Hopedale, Ohio.

Prior to this demonstration, a feasibility study was conducted by FCE to evaluate the availability and quality of coalmine methane (CMM) at a site operated by Northwest Fuel Development and owned by Harrison Mining Corporation (now owned by AEP Ohio Coal LLC) near Cadiz, Ohio. This study indicated that gas quality and quantity was sufficient to operate a fuel cell power plant in the $30-300 \mathrm{~kW}$ range. Based on the gas available at the site and available fuel cell technology, a conceptual design and cost estimate was prepared by FCE (1999) recommending the use of a sub-megawatt (subMW) fuel cell power plant for operation on CMM at the Ohio site. In September 2000 a cooperative agreement was signed with the U.S. Department of Energy (DOE) to demonstrate an FCE subMW fuel cell power plant on CMM at the Ohio site.

The CMM was analyzed prior to installation of the fuel cell and contained $42 \%$ Methane with a heating value of $393 \mathrm{Btu} / \mathrm{ft}^{3}$. Oxygen in the coalmine methane was analyzed at $0.05 \%$, and was less than expected. Moisture content was at saturation, which generally was not an issue except during very cold weather when freeze-up could occur. The methane content measured prior to the installation of the fuel cell power plant in 2003 was significantly lower than the $68 \%$ methane content measured in 2000 . While this was a significant reduction in methane concentration compared to the expected concentration, it was felt that testing on this low quality coal mine methane would be useful in characterizing performance for gas of this quality, and would be a more stringent test demonstrating fuel cell operations achievable in a broader coal mine methane market. Higher quality gas, where available, would be expected to provide equal or better performance.

In parallel to the site preparations, a subMW DFC power plant was prepared for operation on CMM. Deoxidation catalyst was installed to remove the oxygen expected in the coalmine methane. In addition, flow measurement and control valves were installed to handle the anticipated higher throughput when operating on CMM.

The fuel cell power plant was operated on CMM between August 1, 2003 and December 13, 2003. During this period 1456 hours on-load operation was achieved. The total power generated using CMM was 134 megawatt-hours (MWh) of electricity. The power generated was connected to the American Electric Power grid by a 69 kilovolt $(\mathrm{kV})$ transformer. The maximum power level achieved was $140 \mathrm{~kW}$. This is lower than achieved on pipeline natural gas due to flow rate limitations of the equipment. This constraint can be eliminated by appropriate design modifications for low Btu fuel. Efficiency of power generation was $40 \%$ based on the lower heating value (LHV) of the CMM. Compression and drying of the CMM resulted in additional parasitic load, which reduced the efficiency to $36 \%$ LHV. In future applications, on-board compression and utilization of the saturated CMM without drying will be investigated in order to reduce the auxiliary power requirements. Table 1 summarizes key parameters of the fuel cell power plant operation. By comparison, the internal combustion engines operating on CMM at the Hopedale site operate at an efficiency of $24 \%$. When factoring in the compression energy and exhaust gas blower they utilize, the over-all efficiency for the engines is $20 \%$. The overall 
efficiency for the fuel cell is therefore $80 \%$ higher than the internal combustion engine (36\% vs. $20 \%$ ).

\section{Table ES-1. CARBONATE FUEL CELL POWER PLANT (HM-4R) OPERATIONS ON COAL MINE METHANE: \\ High efficiency operation on low Btu CMM demonstrated}

\begin{tabular}{|l|c|}
\hline Operating Period (days) & 133 \\
\hline Hours on load & 1456 \\
\hline Max net power (kW) & 140 \\
\hline Coal Mine Methane flow rate at $140 \mathrm{~kW}$ (SCFM) & 50.9 \\
\hline Efficiency (\%LHV) (not including compression and drying) & 40.1 \\
\hline
\end{tabular}

The availability for the fuel cell power plant was lower than observed with natural gas operation. Field operations on CMM resulted in several failures of the gas drying equipment and one failure of the gas compressor. Both of these were special equipment items for CMM application. The dryer in this demonstration utilized electrically driven control valves to switch between drying and regeneration of two molecular sieve beds. These valves had a high rate of failure and required several repairs by the manufacturer. Future CMM applications should be modified to either operate on saturated CMM directly (without a dryer), or with a high reliability dryer system. The CMM compressor failed once due to freeze up on the return line regulator. In addition, the water delivery system experienced cold weather freeze-up problems when water froze in the backup spring water supply system. This can be corrected in future CMM applications by insuring that the water delivery system is designed properly for cold weather operations. The $69 \mathrm{kV}$ transformer at the site required repair due to leaking bushings, causing a temporary halt in power generation. There were some interruptions caused by standard fuel cell balance of plant equipment, including a leaking pressure relief valve, leaking water valve, water treatment system failure, and a short in the fuel cell startup heater. These items contributed to reduced availability of the power plant. These causes have been or are being addressed in standard power plant improvement efforts at FCE.

The fuel cell power plant tested was capable of $200 \mathrm{~kW}$ on natural gas. Due to the lower methane content of the CMM (42\%), the total gas throughput was increased compared to natural gas, and power output was reduced. The maximum power achieved was $140 \mathrm{~kW}$. For future applications using dilute coalmine methane, flow control instruments and pressure drops need to be designed for higher gas throughput in order to achieve the rated output of the power plant. On a Btu feed basis, performance on the low Btu CMM tested was comparable to natural gas.

Post-test analysis of the carbon beds, deoxidizer catalyst, and prereformer catalyst indicated no adverse effect of operation in terms of loss of surface area or effectiveness of the catalysts and sulfur sorbent. After completion of the CMM testing, the fuel cell power plant was removed from the site. All fuel cell related equipment was removed and the site was restored.

The conclusions drawn from this demonstration on coalmine methane are:

1. Operation of the fuel cell in this demonstration test utilized 1,795,556 standard cubic feet (SCF) of $\mathrm{CH}_{4}$ as CMM. This is equivalent to: a) avoiding 725 metric tons of carbon dioxide emissions, b) avoiding 1.6 million pounds of carbon dioxide emissions, c) 
removing 160 cars off the road for one year, d) heating 26 households for 1 year, e) planting 218 acres of trees. (Reference: U.S. Environmental Protection Agency, Coalbed Methane Outreach Program, http://www.epa.gov/coalbed/resources/converter.html)

2. The direct fuel cell can operate on low-Btu CMM with $\sim 40 \%$ methane content and achieve performance comparable to natural gas on a Btu feed basis.

3. Deoxidation of CMM was effective although low oxygen content was observed in the CMM tested.

4. Variations in CMM flow did not pose problems in the operation of the fuel cell power plant. The plant was monitored on site daily and adjustments were made as needed. It is anticipated that future power plants operating unattended will be programmed for automatic control to handle variations in CMM flow.

5. Utilization of fuel cells to mitigate CMM emissions is an attractive option that can be utilized to generate power at high efficiencies and with very low emissions.

6. Elimination of the need for drying CMM should be explored by using flow measurement methods that are insensitive to moisture.

7. Energy required for compression and drying of coal mine methane should be minimized to maximize overall power plant efficiency.

8. The economics of power generation utilizing the Direct FuelCell will be driven by the capital cost of the fuel cell and local electricity rates. At current costs, subsidies are required to make the cost of electricity competitive. FCE is currently engaged in an aggressive cost reduction program to reduce capital cost of the fuel cell power plant. It is therefore anticipated that future power plants will produce power at competitive costs utilizing CMM. Future emissions credits will help realize this goal as well.

9. Future operation of a $250 \mathrm{~kW}$ Fuel Cell Power Plant on CMM for one year will utilize $18,400,000$ cubic feet of methane. This will be equivalent to: a) avoiding 7428 metric tons of $\mathrm{CO}_{2}$ emissions, b) avoiding 16.4 million pounds of $\mathrm{CO}_{2}$ emissions, c) removing 1640 cars off the road for one year, d) heating 267 households for 1 year, d) planting 2234 acres of trees. (Reference: U.S. Environmental Protection Agency, Coalbed Methane Outreach Program, http://www.epa.gov/coalbed/resources/converter.html) 


\section{EXPERIMENTAL}

\section{A. Design and Construction}

\section{Fuel Cell Power Plant Description}

The sub megawatt fuel cell power plant consists of three subsystems, mounted on a common base frame and contained within a full enclosure as shown in Figure 2 below. The elements of the power plant include:

- Direct Fuel Cell

- Mechanical Balance of Plant (MBOP)

- Electrical Balance of Plant (EBOP)

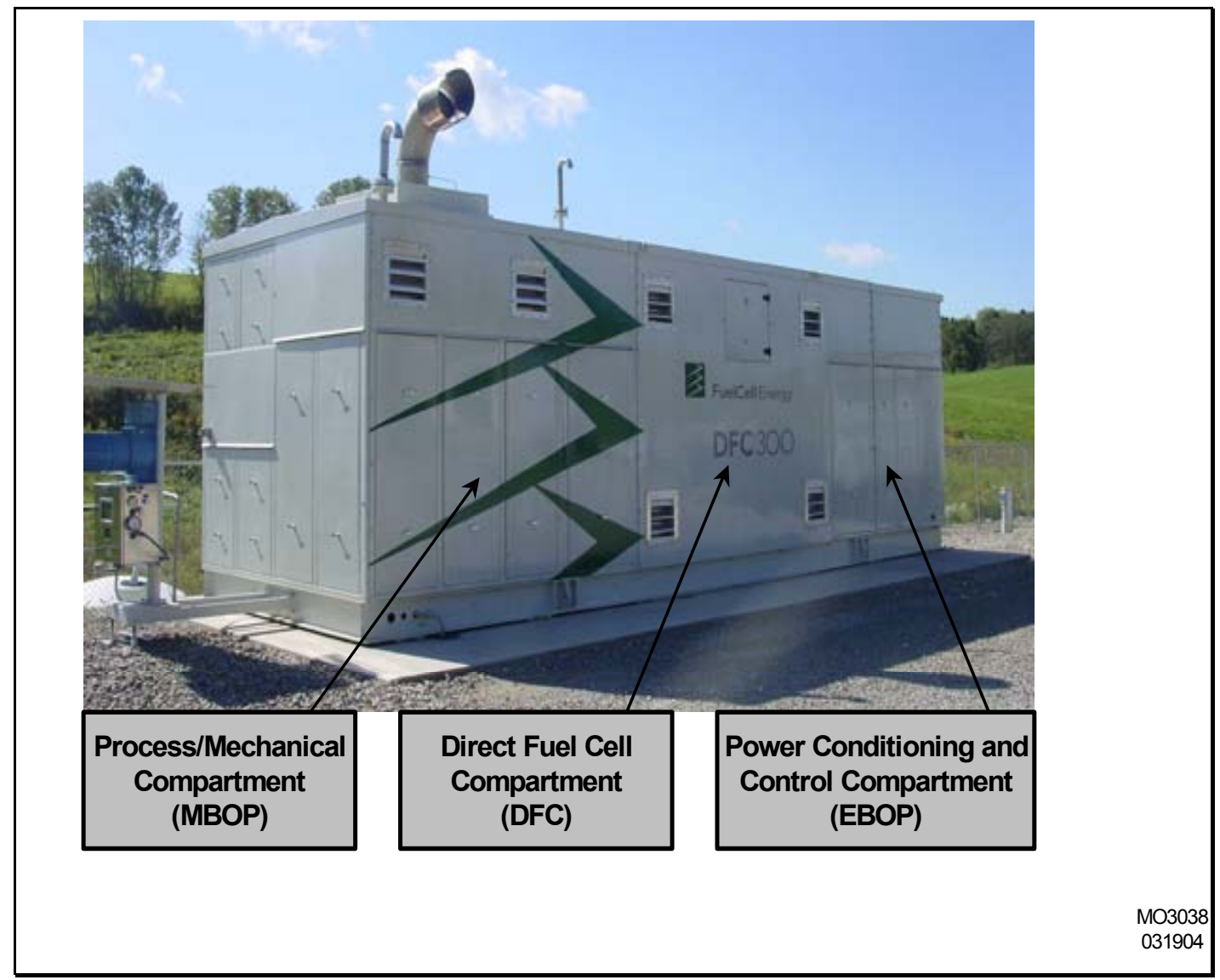

Figure 2. SUBMEGAWATT FUEL CELL POWER PLANT:

Contains three major subsystems, MBOP, DFC, EBOP

The plant is designed for unattended operation with local and remote dispatching/control. The unit has a local control panel that is limited to displaying operating mode and inputs for selecting desired power output level or mode transition. Additional data and controls are provided through local computer hookup or remote computer monitor stations. 
a) Fuel Cell Module - The fuel cell module, shown in Figure 3 below contains the fuel cell stack, and auxiliary equipment, including the catalytic oxidizer, fuel superheater, and startup heater. The fuel cell stack consists of 341 carbonate fuel cells of nominal $9-\mathrm{ft}^{2}$ area in horizontal configuration. Table 6 below summarizes the features of this fuel cell stack.

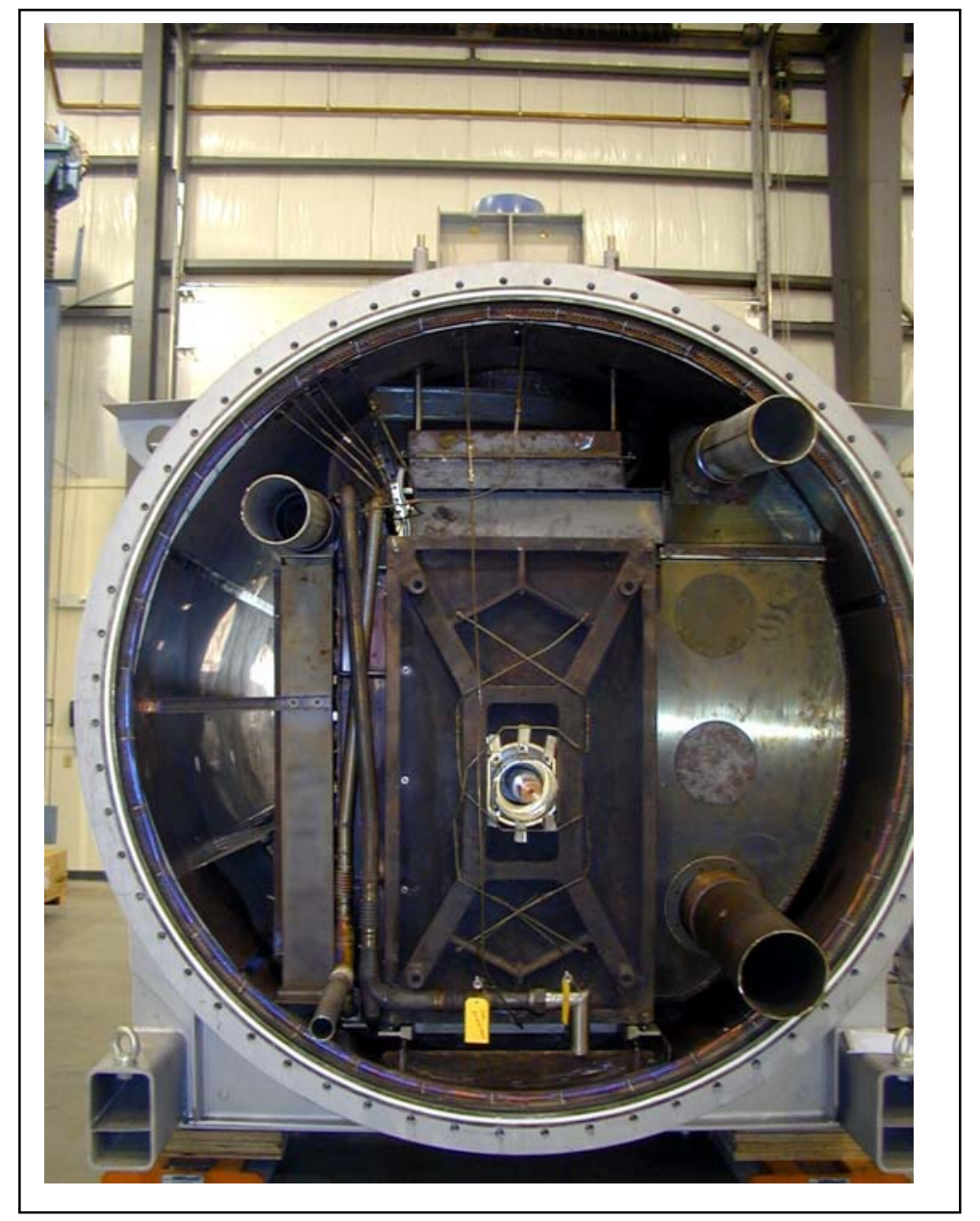

Figure 3. SUBMEGAWATT FUEL CELL MODULE USED FOR CMM TESTING:

First generation fuel cell module previously tested on natural gas at Los Angeles Department of Water and Power

Table 6. SUBMEGAWATT FUEL CELL MODULE USED FOR COAL MINE METHANE TESTING:

Horizontal fuel cell configuration used based on the MTU design

\begin{tabular}{|l|c|}
\hline Fuel Cell Type & Direct Carbonate Fuel Cell \\
\hline Number of Cells & 341 \\
\hline Cell Area $\left(\mathrm{ft}^{2}\right)$ & 9 \\
\hline Stacking configuration & Horizontal \\
\hline Operating Temperature (F) & $1100-1200$ \\
\hline Fuel Utilization $(\%)$ & 68 \\
\hline
\end{tabular}


b) Mechanical Balance of Plant (MBOP) - The MBOP contains fuel treatment, deoxidation, prereforming and heat recovery in one compartment; water treatment and process air blower in a separate compartment;

The fuel gas enters the plant and flows through two carbon beds to remove sulfur. The fuel gas is humidified in the FCE-developed humidifying heat exchanger using deionized water and desulfurized fuel. The moisturized fuel flows to a deoxidizer to remove any oxygen, a preconverter to remove higher hydrocarbons, and then to the fuel cell stack module. Figure 4 shows a simplified process flow diagram of this process.

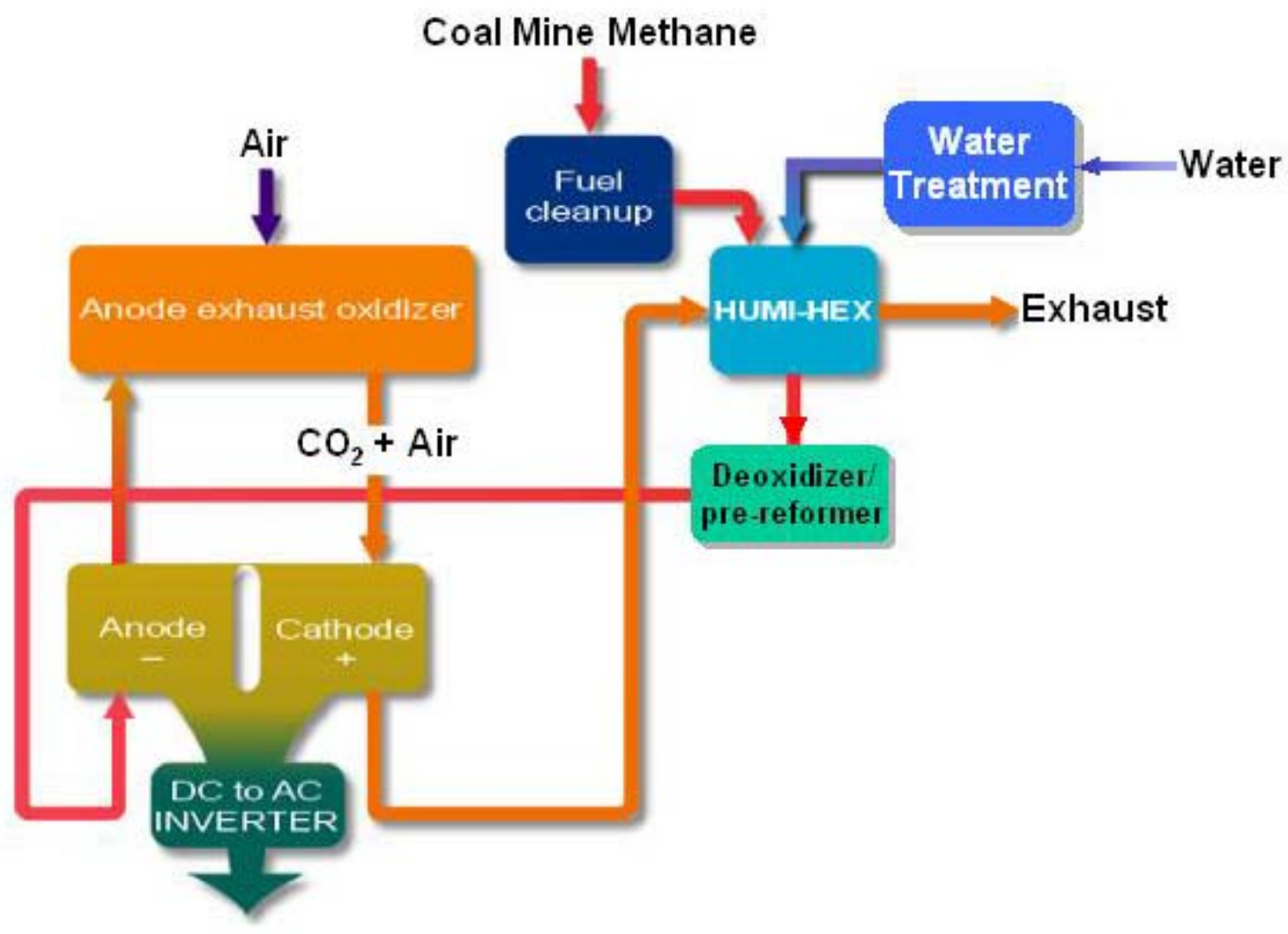

Figure 4. SIMPLIFIED PROCESS FLOW DIAGRAM:

Deoxidation step added for CMM operation

The plant is designed to operate with municipal potable water makeup that meets the criteria listed in Table 7. These criteria were used in estimating specifications for the water treatment system. The performance water criteria listed in the table is the basis used for estimating the plant's water treatment requirement. The spring water at the Hopedale site was analyzed and is listed in the last column. It is slightly higher in bicarbonate, sulfates and hardness compared to the design range and may require more frequent maintenance intervals.

c) Electrical Balance of Plant (EBOP) - The EBOP contains the power conditioning unit, which provides the 480 Volt AC power suitable for grid operation, motor control center, transformers, the user interface (HMI), and control system. 
Table 7. WATER QUALITY REQUIREMENTS FOR FUEL CELL PLANT OPERATION:

The onboard water treatment system is design to treat this quality of water

\begin{tabular}{|c|c|c|c|}
\hline & $\begin{array}{l}\text { DESIGN } \\
\text { RANGE } \\
\text { BASIS } \\
\end{array}$ & $\begin{array}{l}\text { PERFORMANCE } \\
\text { WATER }\end{array}$ & $\begin{array}{l}\text { Hopedale, OH } \\
\text { ROSE VALLEY } \\
\text { SITE ANALYSIS }\end{array}$ \\
\hline \multicolumn{4}{|l|}{ Quality } \\
\hline Calcium (Ca), mg/l as $\mathrm{CaCO}_{3}$ & $0-120$ & 44 & 41 \\
\hline Magnesium (Mg), $\mathrm{mg} / \mathrm{l}$ as $\mathrm{CaCO}_{3}$ & $0-50$ & 16 & 10 \\
\hline Sodium $(\mathrm{Na}), \mathrm{mg} / \mathrm{l}$ & $0-30$ & 16 & $<0.5$ \\
\hline Bicarbonate $\left(\mathrm{HCO}_{3}\right), \mathrm{mg} / \mathrm{l}$ as $\mathrm{CaCO}_{3}$ & $0-90$ & 50 & 95 \\
\hline Chloride $(\mathrm{Cl}), \mathrm{mg} / \mathrm{l}$ & $0-50$ & 17 & $<0.4$ \\
\hline Sulfate $\left(\mathrm{SO}_{4}\right), \mathrm{mg} / \mathrm{l}$ & $0-90$ & 20 & 151 \\
\hline $\mathrm{S}$ Cations, $\mathrm{mg} / \mathrm{l}$ as $\mathrm{CaCO}_{3}$ & $0-150$ & & \\
\hline $\mathrm{S}$ Anions, $\mathrm{mg} / \mathrm{l}$ as $\mathrm{CaCO}_{3}$ & $0-150$ & & \\
\hline Alkalinity, mg/l as $\mathrm{CaCO}_{3}$ & $0-150$ & & \\
\hline Nitrate, $\mathrm{mg} / \mathrm{l}$ as $\mathrm{CaCO}_{3}$ & $0-5$ & & \\
\hline Total Dissolved Solids, mg/l & $0-350$ & 135 & 236 \\
\hline Total Hardness as $\mathrm{CaCO}_{3}, \mathrm{mg} / \mathrm{l}$ & $0-150$ & 60 & 177 \\
\hline Silica $\left(\mathrm{SiO}_{2}\right), \mathrm{mg} / \mathrm{l}$ & $0-100$ & 3 & \\
\hline Iron $(\mathrm{Fe}), \mathrm{mg} / \mathrm{l}$ & $0-0.3$ & 0.03 & \\
\hline Copper (Cu), mg/l & $0-0.5$ & 0.01 & \\
\hline Manganese (Mn), mg/l & $0-0.1$ & & \\
\hline Zinc $(\mathrm{Zn}), \mathrm{mg} / \mathrm{l}$ & $0-0.1$ & & \\
\hline Barium (Ba), mg/l & $0-0.01$ & & \\
\hline Total Organic Carbon (TOC), mg/l & $0-5$ & & \\
\hline Chlorine, mg/l & 0.05 & & \\
\hline Silt Density Index & $0-5$ & 2 & \\
\hline Color, Standard Units & $0-10$ & & \\
\hline Turbidity (NTU) & $0-1$ & & \\
\hline Suspended Solids (SS), mg/l & $0-0.5$ & & \\
\hline Specific Conductance, micromho/cm & $0-580$ & 205 & \\
\hline 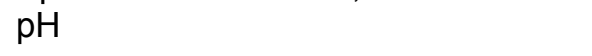 & $7-10$ & 7.6 & 6.4 \\
\hline \multicolumn{4}{|l|}{ Conditions } \\
\hline$\overline{\text { Temperature, }}{ }^{\circ} \mathrm{F}$ & $40-90$ & 59 & \\
\hline Pressure, psig & $50-65$ & 60 & \\
\hline
\end{tabular}

(1) Basis used for estimating the $250 \mathrm{~kW}$ Power plant water treatment requirements 


\section{2. $\quad$ Site Description and Preparation}

The Rose Valley test site is located in Hopedale, Ohio, a one-hour drive west of Pittsburgh. A link to a topographic map showing the site marked by a red cross follows:

http://www.topozone.com/map.asp? $z=17 \& n=4462531.00011736 \&==508713 \&$ datum=nad83.

Northwest Fuel Development Inc. operates the site for power generation with internal combustion engines using coalmine methane under an agreement with Ohio Coal LLC and the landowner, Mr. James Carson. Space was made available for the fuel cell power plant at the site and all the required interfaces were installed. The IC engines and the fuel cells shared the methane from Nelms \#1 vent. Figure 5 shows a photo of the Rose Valley Test site taken before installation of the fuel cell.

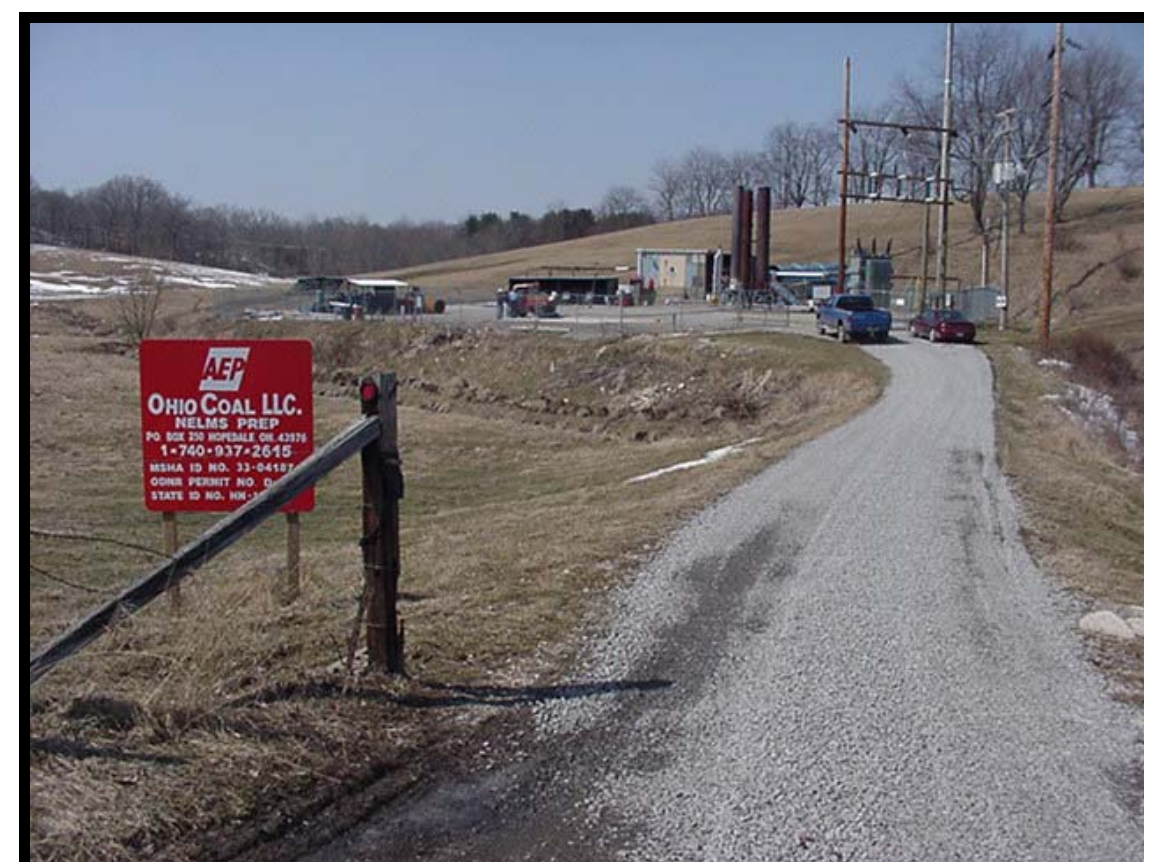

\section{Figure 5. ROSE VALLEY COAL MINE METHANE TEST SITE IN HOPEDALE, OHIO:}

The site is located 60 miles west of Pittsburgh

The plot plan of the site, shown in Figure 6, shows the location of the fuel cell power plant in the southeast corner of the site. There are two gas vents at the site, Nelms \#1 and Nelms \#2. Both vents are tied into a common header and can be valved on individually. Nelms \#1 vent is the vent that supplied fuel gas to the fuel cell and the IC engines operating at the site by Northwest Fuel Development. The gas for the fuel cell is piped underground to the compressor and dryer pad located on the west end of the site. The compressed and dry gas is then piped underground to the fuel cell foundation on the southeast end of the site. Water is supplied from a water well located on the south side of the site. A spring water tank on the west end of the site supplements this water supply. Power is supplied and transmitted through a breaker panel on the north side of the site. The power generated by the fuel cell and the engines is transformed to $69 \mathrm{kV}$ by a transformer located on the northeast side of the site and connected to the American Electric Power (AEP) grid. 


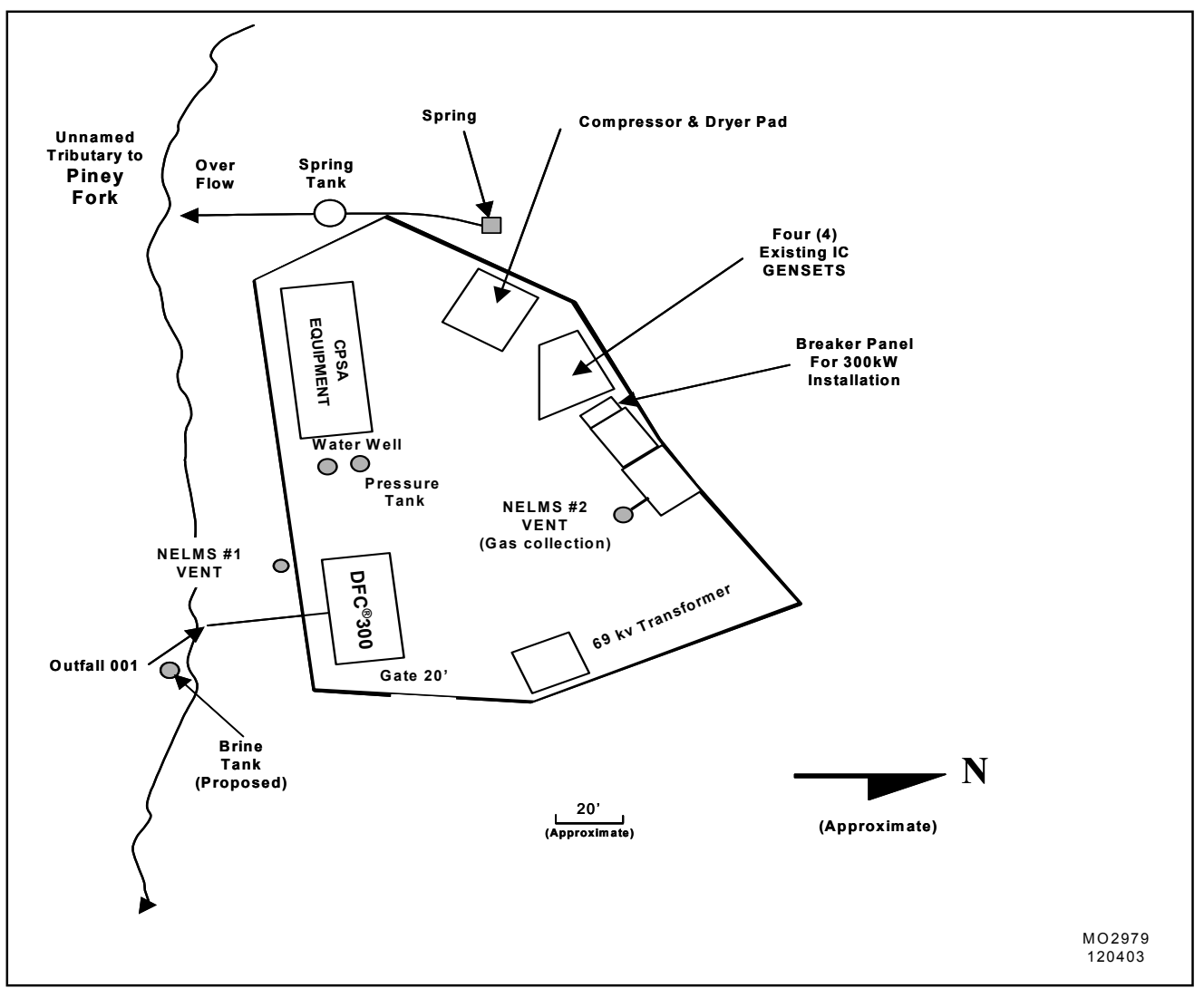

Figure 6. PLOT PLAN OF THE ROSE VALLEY COAL MINE METHANE TEST SITE IN HOPEDALE, OHIO:

The fuel cell was installed in the southeast corner of the site where internal combustion engines operate on CMM

\section{a) Coal Mine Methane Gas Quality}

Gas analysis of the coalmine methane at the Rose Valley site indicated the methane content was about $42 \%$. This was based on gas chromatographs that were taken during the test period. Table 8 below shows the results obtained.

Analysis of a grab sample taken on March 11, 2003 and sent to Gas Analysis Services, Inc in Bridgeport, WV is shown in the Appendix. This sample indicated 39.9\% methane and traces of butane, pentane and hexanes. In addition, this sample also indicated a higher oxygen level, possibly due to air infiltration during sampling or insufficient purge of the sample container. Gas analysis by on-line GC during the test period indicated oxygen to be very low, on the order of the analysis $0.05 \%$.

In the period between January 1999 and November 2000 analysis of the gas indicated methane levels at $60 \%$ to $76 \%$ with oxygen level at $0.17 \%$ to $1.33 \%$. In the period between 2000 and 2003 the methane content decreased to $42 \%$ as indicated above in Table 6. 
Table 8. GAS ANALYSIS OF COAL MINE METHANE AT THE ROSE VALLEY TEST SITE:

Methane content prior to the start of fuel cell operations was $42 \%$

\begin{tabular}{|c|c|}
\hline Component & Mole \% \\
\hline Methane & 42.4 \\
\hline Ethane & 0.43 \\
\hline Propane & 0.04 \\
\hline Nitrogen & 50.91 \\
\hline Carbon Dioxide & 6.07 \\
\hline Oxygen & 0.05 \\
\hline Heating Value (LHV), Btu $/ \mathrm{ft}^{3}$, dry & 393 \\
\hline
\end{tabular}

The trace contaminant levels in the coalmine methane are shown below in Table 9. The data indicates very low levels of these contaminants.

Table 9. TRACE CONTAMINANT LEVEL IN COAL MINE METHANE ${ }^{(3)}$ :

Sulfur in the CMM is less than $0.2 \mathrm{ppm}$

\begin{tabular}{|l|l|l|l|l|l|}
\hline Component & $\begin{array}{l}\text { Detectable } \\
\text { Limit, } \\
\text { ppm }\end{array}$ & $\begin{array}{l}\text { Measurable } \\
\text { Range } \\
\text { Low } \\
\text { ppm }\end{array}$ & $\begin{array}{l}\text { Measurable } \\
\text { Range, } \\
\text { High, } \\
\text { ppm }\end{array}$ & $\begin{array}{l}\text { Rose Valley } \\
\text { Vent \#1 } \\
\text { ppm } \\
\text { measured }\end{array}$ & $\begin{array}{l}\text { Rose Valley } \\
\text { Vent \#2 } \\
\text { ppm } \\
\text { measured }\end{array}$ \\
\hline Chlorine & 0.01 & 0.05 & 2 & $<0.01$ & $<0.01$ \\
\hline $\mathrm{HCl}$ & 0.2 & 0.4 & 40 & $+/-0.2$ & $<0.2$ \\
\hline $\mathrm{H}_{2} \mathrm{~S}$ & 0.2 & 0.5 & 40 & $<0.2$ & $<0.2$ \\
\hline Mercaptans & 0.2 & 0.5 & 10 & $<0.2$ & $+/-0.2$ \\
\hline
\end{tabular}

\section{b) Gas Compressor}

The ambient pressure coalmine methane from the vent needs to be compressed to 15 psig for use in the fuel cell power plant. The gas compressor specified and recommended by Northwest Fuel Development is shown in the Appendix. The process flow diagram for the compressor is shown in Figure 7. A photo of the compressor is shown in Figure 8.

\section{c) Gas Dryer}

Coalmine methane comes out of the ground saturated with water. Therefore condensation of water is expected. The current fuel flow measurement device on the fuel cell power plant is based on mass flow and cannot function if water droplets are present in the gas being measured. Therefore it is necessary to provide a dry gas. In addition, during cold weather conditions, condensed moisture can result in freezing and blockage of the fuel line. For these reasons a dryer was installed to insure that a dry fuel gas is supplied to the fuel cell. A heat activated continuous duty closed loop regenerative dryer utilizing a molecular sieve was selected. The dryer was built by Pioneer (model LCNG200S), and its features are shown in the appendix. Figure 9 shows the dryer installed at the test site. 


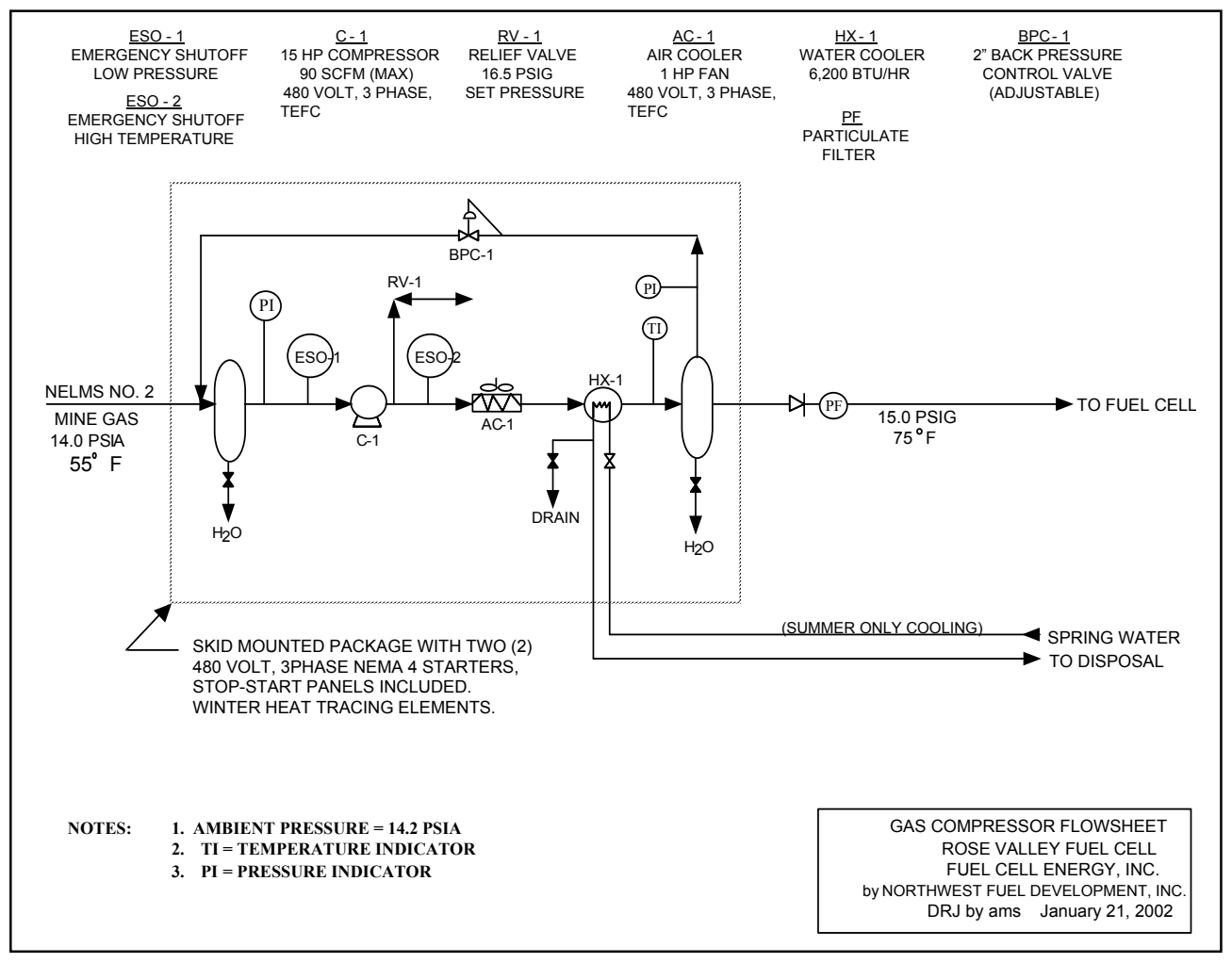

Figure 7. PROCESS FLOW DIAGRAM FOR COAL MINE METHANE COMPRESSOR:

The CMM compressor was designed with the required cooling

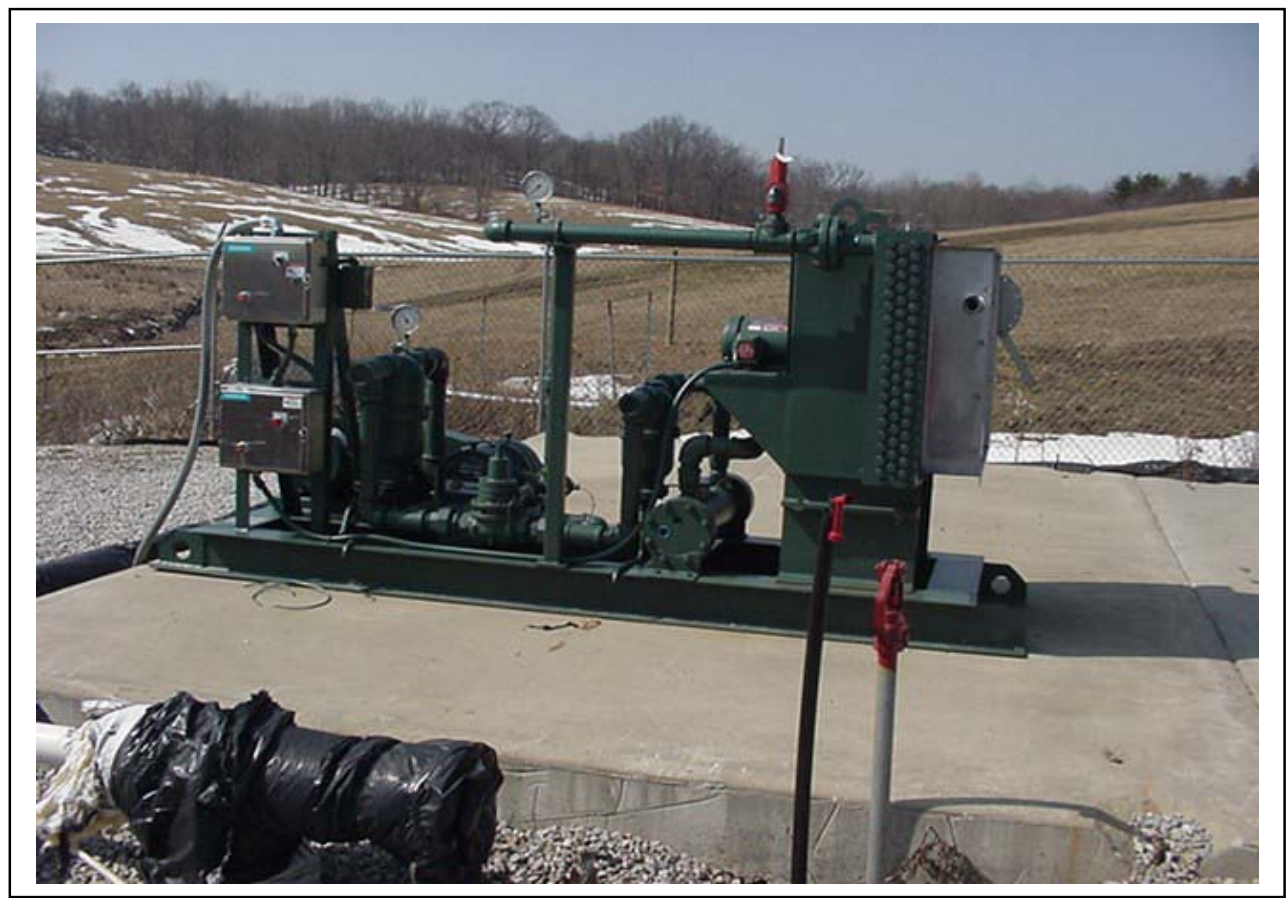

Figure 8. COAL MINE METHANE COMPRESSOR AT THE ROSE VALLEY TEST SITE:

The compressor was installed on an existing concrete pad 


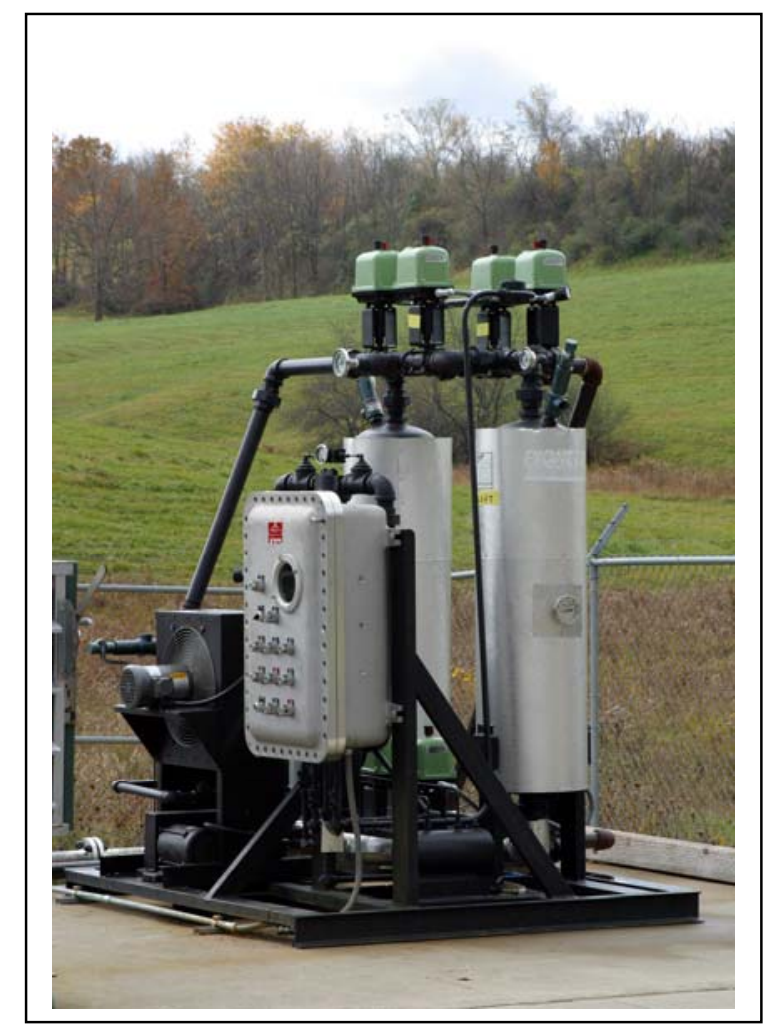

Figure 9. GAS DRYER INSTALLED AT ROSE VALLEY FOR COAL MINE METHANE:

The dryer was installed next to the compressor

d) Transformer

A $69 \mathrm{kV}$ transformer was installed at the site to upgrade the capacity for power transmission to accommodate both fuel cell power and IC engine power generation. Northwest Fuel Development provided the transformer and FCE shared in the cost. Figure 10 shows a photo of the transformer.

Figure 10. $69 \mathrm{kV}$ TRANSFORMER AT THE ROSE VALLEY SITE USED FOR CONNECTING FUEL CELL POWER TO THE AEP GRID:

This transformer was already in use at the site by the IC engines in place

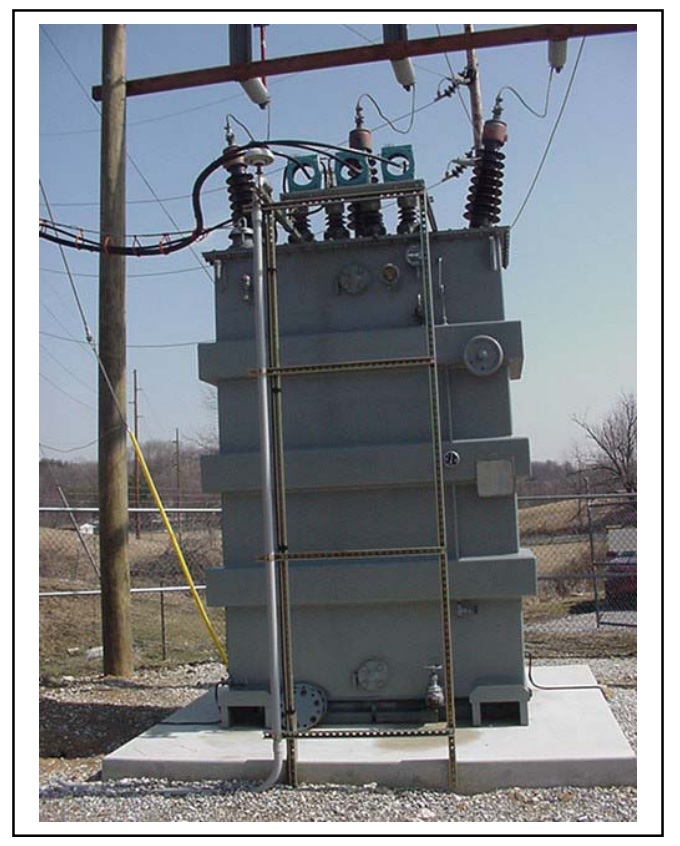


e) Water Supply System

The water supply system included a water well and a spring water supply. A schematic of this system is shown in Figure 11. The water well was drilled at the site to supply the water needed by the fuel cell. After drilling the well it was determined that only 1 GPM was available from this well whereas 3.4 GPM was needed intermittently to fill the DI water tank on board the fuel cell power plant. A nearby spring water supply was therefore used to supplement the water available to the fuel cell. The spring water supply had a supply rate of 4 GPM, meeting the total needed by the fuel cell power plant. An underground storage tank was installed to collect spring water and a pump was installed to pump this water to the fuel cell water supply when needed. Figure 12 shows the pump controls for both the well water and spring water.

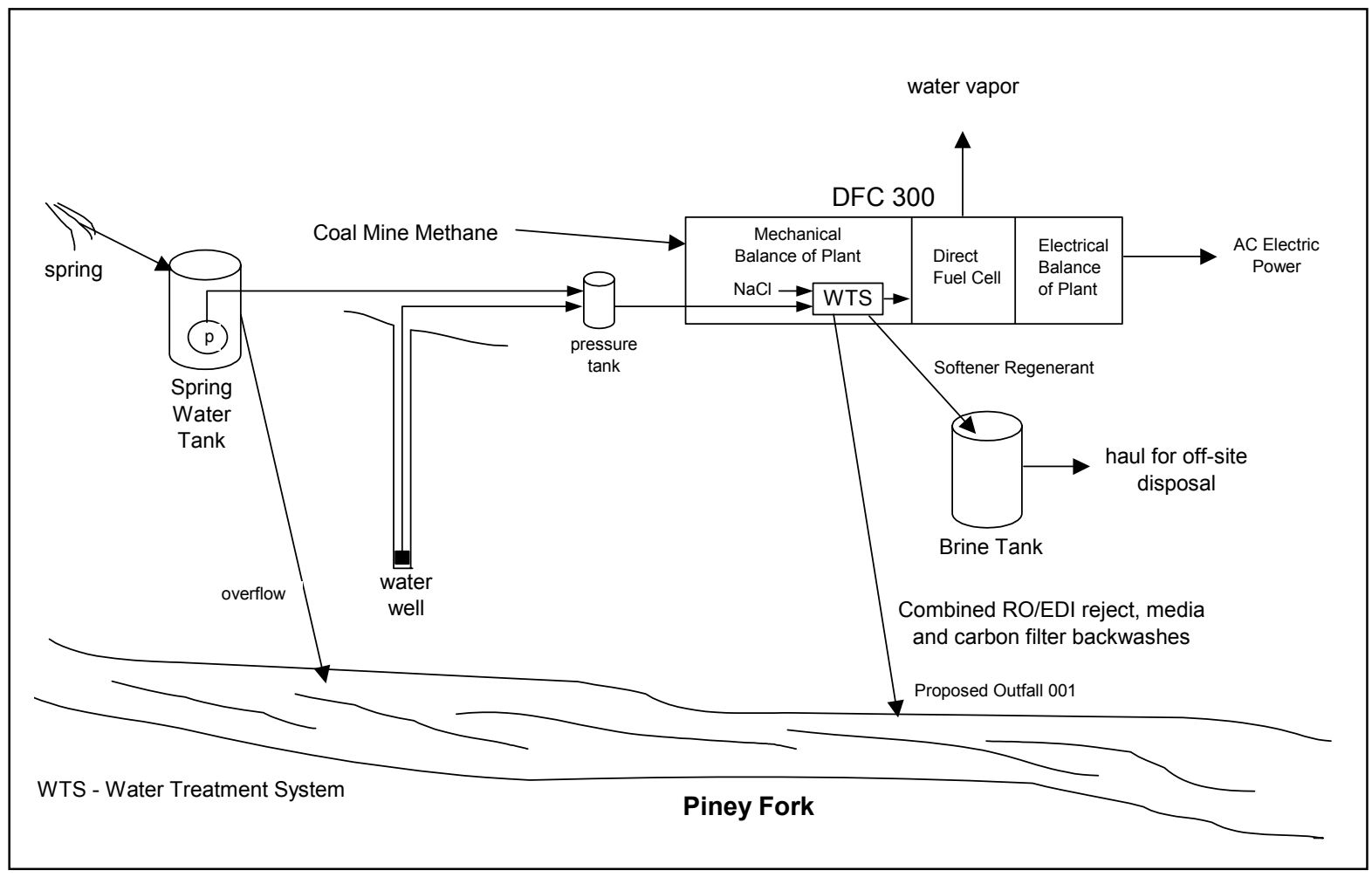

\section{Figure 11. SCHEMATIC OF WATER SUPPLY SYSTEM AT THE ROSE VALLEY TEST SITE:}

A well and a nearby spring supplied water

The spring water quality is shown in Table 10 below.

Table 10. SPRING WATER QUALITY AT ROSE VALLEY TEST SITE:

The spring water quality met the design requirements for the water treatment system, but the $\mathrm{pH}$ was slightly below the 7-10 expected range.

\begin{tabular}{|l|l|l|l|l|l|l|l|l|}
\hline Component & $\mathrm{Ca}$ & $\mathrm{Mg}$ & $\mathrm{Na}$ & $\mathrm{HCO}_{3}$ & $\mathrm{SO}_{4}$ & $\mathrm{Cl}$ & $\mathrm{TDS}$ & $\mathrm{PH}$ \\
\hline Composition, $\mathrm{Mg} / 1$ & 22.7 & 2.4 & 6.2 & 84.0 & 52.7 & 1.5 & 140.0 & 6.4 \\
\hline
\end{tabular}


f) Foundation for the Fuel Cell Power Plant

A foundation was installed for the fuel cell power plant. Water and fuel supplies were arranged to connect to the fuel cell through the foundation to minimize cold weather impact.

g) Emissions permitting

1) Air Emissions

Air emissions from the fuel cell power plant were determined to qualify under two categories of exemptions.

a) Ohio Administrative Code (OAC) Rule 3745-31-03 - Research and Development projects are exempt from permitting. Air contaminant sources at non-production research and development operations with a potential to emit from any air contaminant source of less than one ton per year of any criteria pollutant.

b) Ohio Administrative Code (OAC) Rule 3745-15-05 - Sources of air pollutants that are "de-minimus" are not subject to permitting if emissions are less than 10 $\mathrm{lbs} /$ day.

2) Water discharge

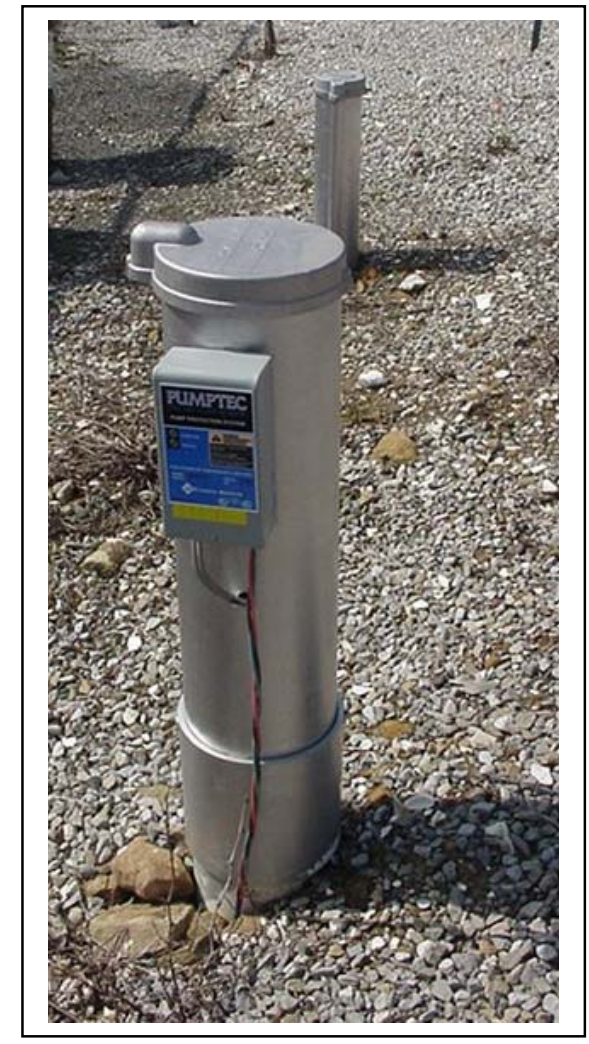

Figure 12. WELL WATER AND SPRING TANK CONTROLS. SPRING TANK PUMP CONTROL IN BACK:

The water supply system was installed for fuel cell

A permit application was prepared and submitted to the Ohio EPA for the water discharge from the on-board water treatment system. The discharge consists of Reverse Osmosis (RO) and Electrodeionization EDI reject as well as media and carbon filter backwash. These discharges were allowed by the Ohio EPA as indicated in the permit obtained by FCE dated October 23, 2002. The brine discharge from the DI water treatment system during regeneration was collected in a brine tank (shown in Figure 11), which was periodically pumped out and hauled away for off site disposal.

\section{B. Power Plant Installation}

The power plant was shipped to the Rose Valley Site in Hopedale, Ohio by low-boy truck (Figure 13). Upon arrival at the site, the fuel cell power plant was lifted off the truck with a crane and set down on its foundation. Figure 14 shows the fuel cell during this operation. The plant was then connected to the coalmine fuel gas, the water supply, water drain, electric power lines, communications lines, and nitrogen cylinders. Figure 15 shows the power plant installed and connected to utilities at the Hopedale, Ohio site. 


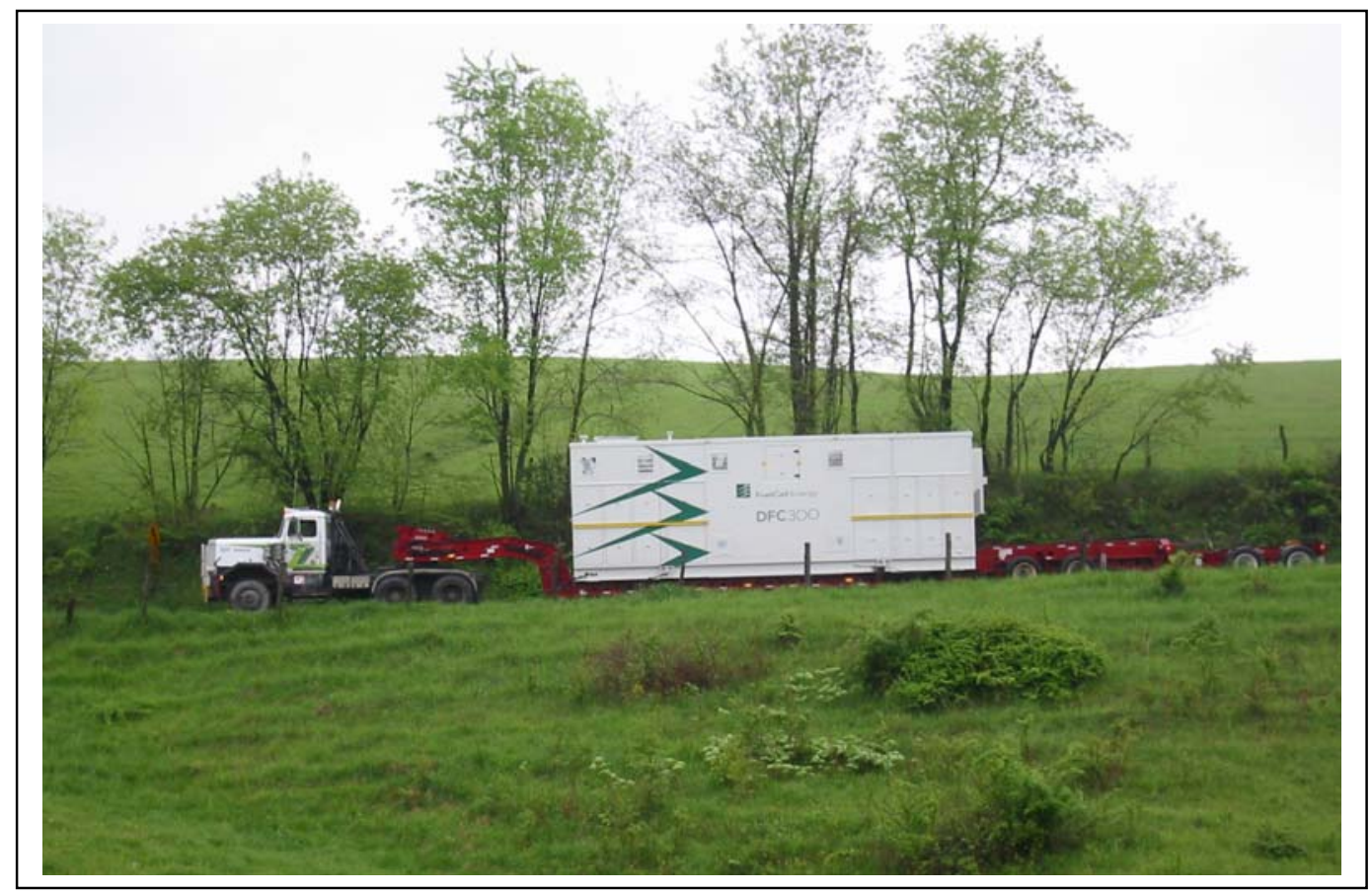

Figure 13. THE FUEL CELL POWER PLANT ARRIVING AT THE HOPEDALE, OHIO SITE:

A low-boy truck trailer transports the fuel cell power plant to its destination

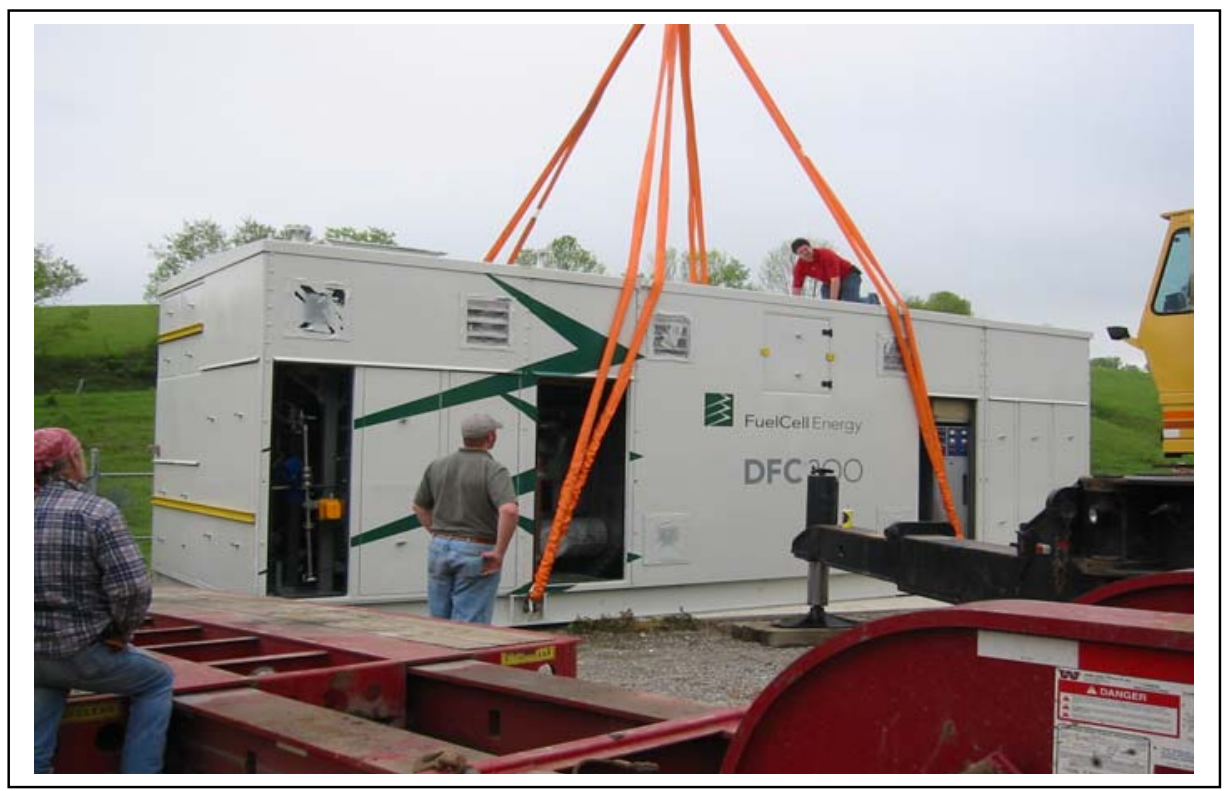

Figure 14. UNLOADING OF THE FUEL CELL POWER PLANT AT THE ROSE VALLEY TEST SITE IN HOPEDALE, OHIO:

A local crane operator lifts the fuel cell off the truck trailer and sets the fuel cell power plant on its foundation 


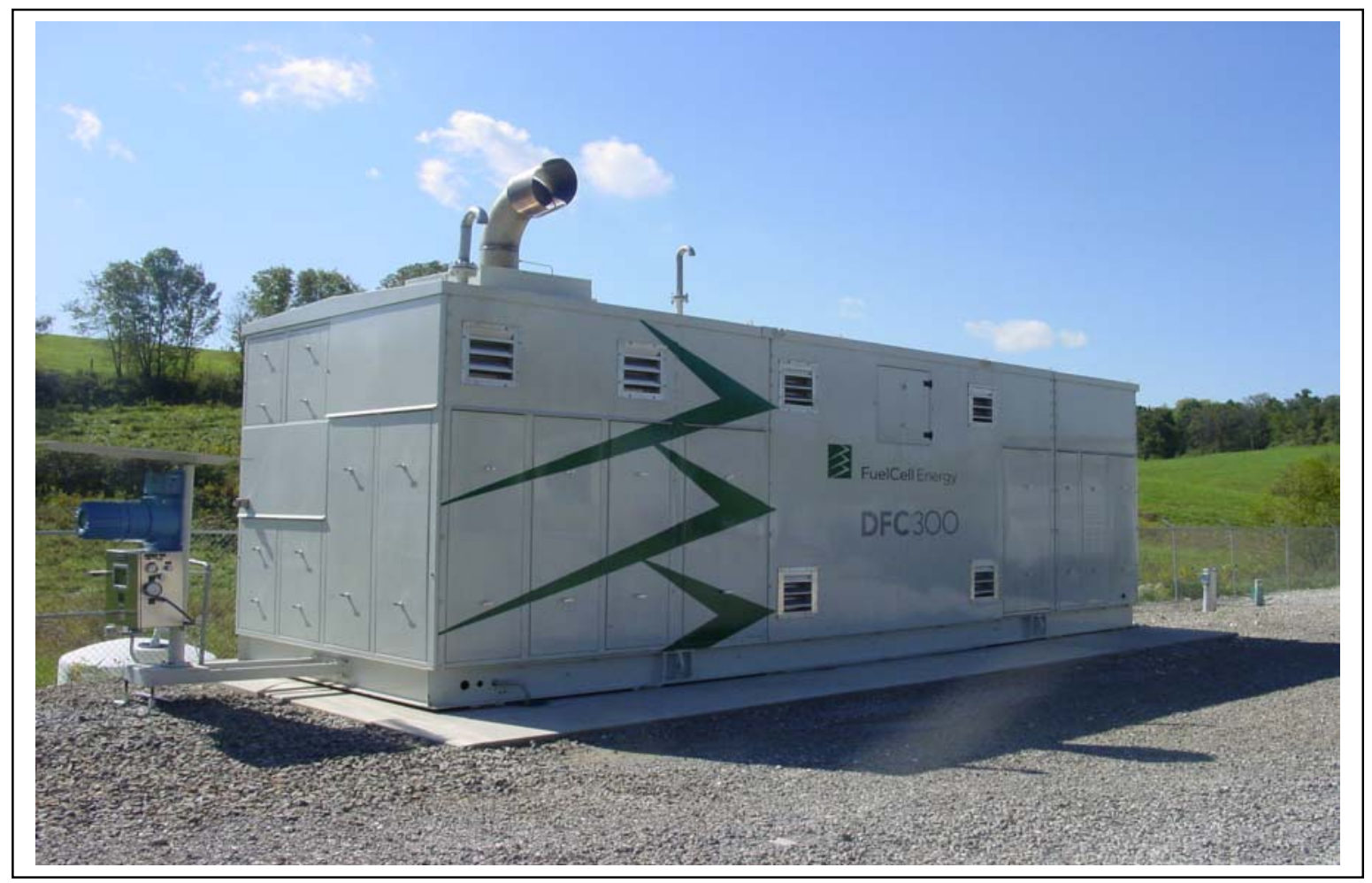

Figure 15. FUEL CELL POWER PLANT INSTALLED AND CONNECTED TO UTILITIES AT HOPEDALE, OHIO TEST SITE:

CMM, water supply, and power lines supplied underground

\section{RESULTS AND DISCUSSION}

Fuel cell power plant operations on coalmine methane were conducted between August 1, 2003 and December 13, 2003. During this period 1456 hours of on-load operations were achieved and no performance penalty compared to natural gas or performance decay was noted. Table 11 below summarizes performance during this operating period.

\section{Table 11. CARBONATE FUEL CELL POWER PLANT (HM-4R) OPERATIONS ON COAL MINE METHANE:}

Operation on low Btu CMM resulted in good performance

\begin{tabular}{|l|c|}
\hline Operating Period (days) & 133 \\
\hline Hours on load & 1456 \\
\hline Max net power (kW) & 140 \\
\hline Coal Mine Methane flow rate at 140 kW (SCFM) & 50.9 \\
\hline Efficiency (\% LHV) (not including compression and drying & 40.1 \\
\hline
\end{tabular}




\section{A. Fuel Cell Power Plant Performance on Coalmine Methane}

\section{Power Level}

The power plant tested was capable of $207 \mathrm{~kW}$ on natural gas. On coalmine methane with $42.4 \%$ methane and a heating value of $393 \mathrm{Btu} / \mathrm{ft}^{3}$, the maximum power level demonstrated was $140 \mathrm{~kW}$. This was achieved at a CMM flow rate of 50.9 SCFM. The maximum calculated flow rate needed to achieve full power $(207 \mathrm{~kW})$ was 70 SCFM.

The 50.9 SCFM flow would have been enough to achieve the $207 \mathrm{~kW}$ power level at the $72 \%$ methane level that was measured at the site when it was first selected for fuel cell testing. However, the methane content of the CMM was significantly lower (42\%) when the fuel cell was installed at the site. At this reduced methane content, the fuel flow required (70 SCFM) exceeded the design limit, and therefore the desired flow could not be achieved. This limitation can be corrected by appropriate design modifications for low Btu fuel operation.

A plot of the net power output to the grid over the operating time of the plant is shown in Figure 16. The total power generated using coalmine methane was $134 \mathrm{MWh}$ of electricity.

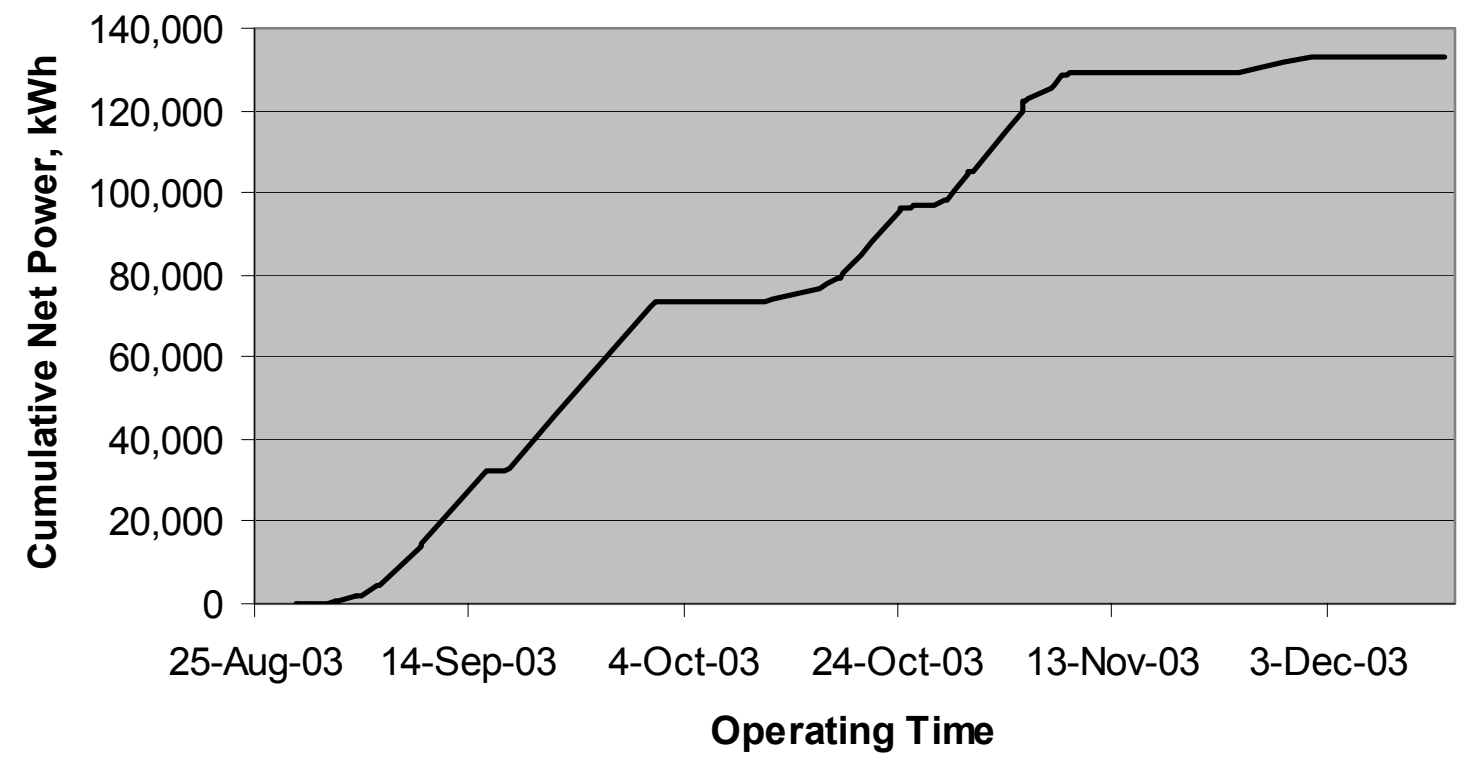

Figure 16. CUMULATIVE POWER OUTPUT ON COAL MINE METHANE:

$134 \mathrm{MWh}$ of electricity was generated on CMM during the test period

\section{Power Plant Efficiency}

At the peak demonstrated power output of $140 \mathrm{~kW}$, the plant efficiency when operating on coalmine methane was $40 \%$. When taking into account the energy used to compress the coalmine methane and to operate the gas dryer the efficiency was $36 \%$. The coalmine methane compressor and dryer used a total of $14 \mathrm{~kW}$. The compressor used $11 \mathrm{~kW}$, and the dryer used 3 $\mathrm{kW}$. 


\section{Stable Operation on Coal Mine Methane}

Stable operation on coal mine methane was observed as shown in Figure 17 below. The data shown was taken at two points in the test program, 700 operating hours apart and at approximately the same operating conditions. No decline in performance was observed on coal mine methane during the period shown as observed by the stack voltage.

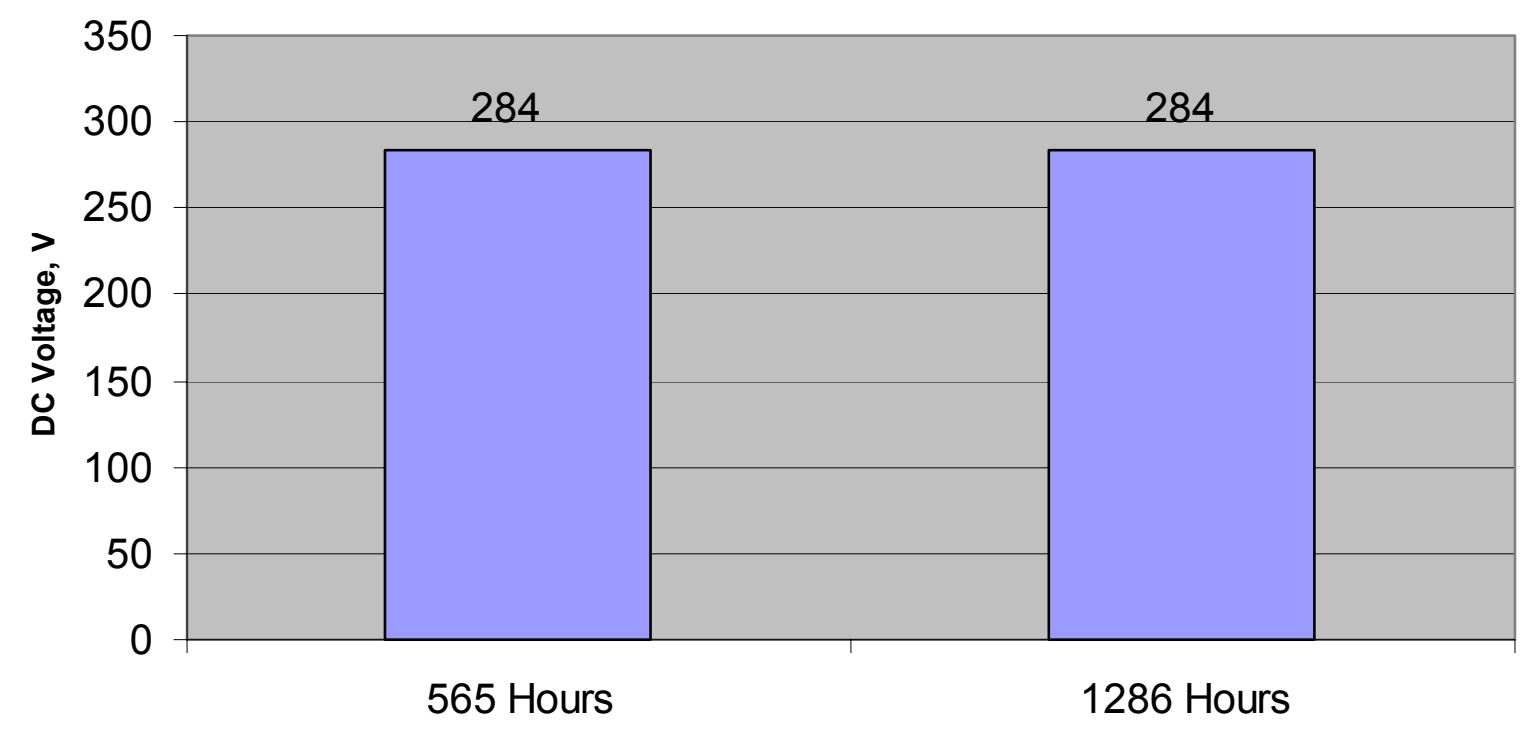

Figure 17. DC STACK VOLTAGE SHOWING STABLE OPERATION ON COAL MINE METHANE:

Net Power 127 kW, Fuel Utilization 57\%, average stack temp 1102 F, coal mine methane flow $51 \mathrm{scfm}$

\section{Comparison to Natural Gas Operation}

Prior to operating on coalmine methane, this power plant operated on natural gas in Los Angeles, CA. The plant ran a total of 3,637 hours at a $207 \mathrm{~kW}$ power level and generated over 750,000 $\mathrm{kWh}$ of electricity. The plant availability was nearly $95 \%$.

The plant performance on natural gas is compared to the performance on coalmine methane in Figure 18. The data indicates that on a Btu feed basis, performance on coalmine methane is very close to performance on natural gas. Since the coal mine methane tested had a Btu value of $393 \mathrm{Btu} / \mathrm{ft}^{3}$, the coal mine methane flow rate had to be higher by a factor of 2.3 to achieve the same power level on coal mine methane compared to natural gas (Btu value of $907 \mathrm{Btu} / \mathrm{ft}^{3}$ ) operation. 


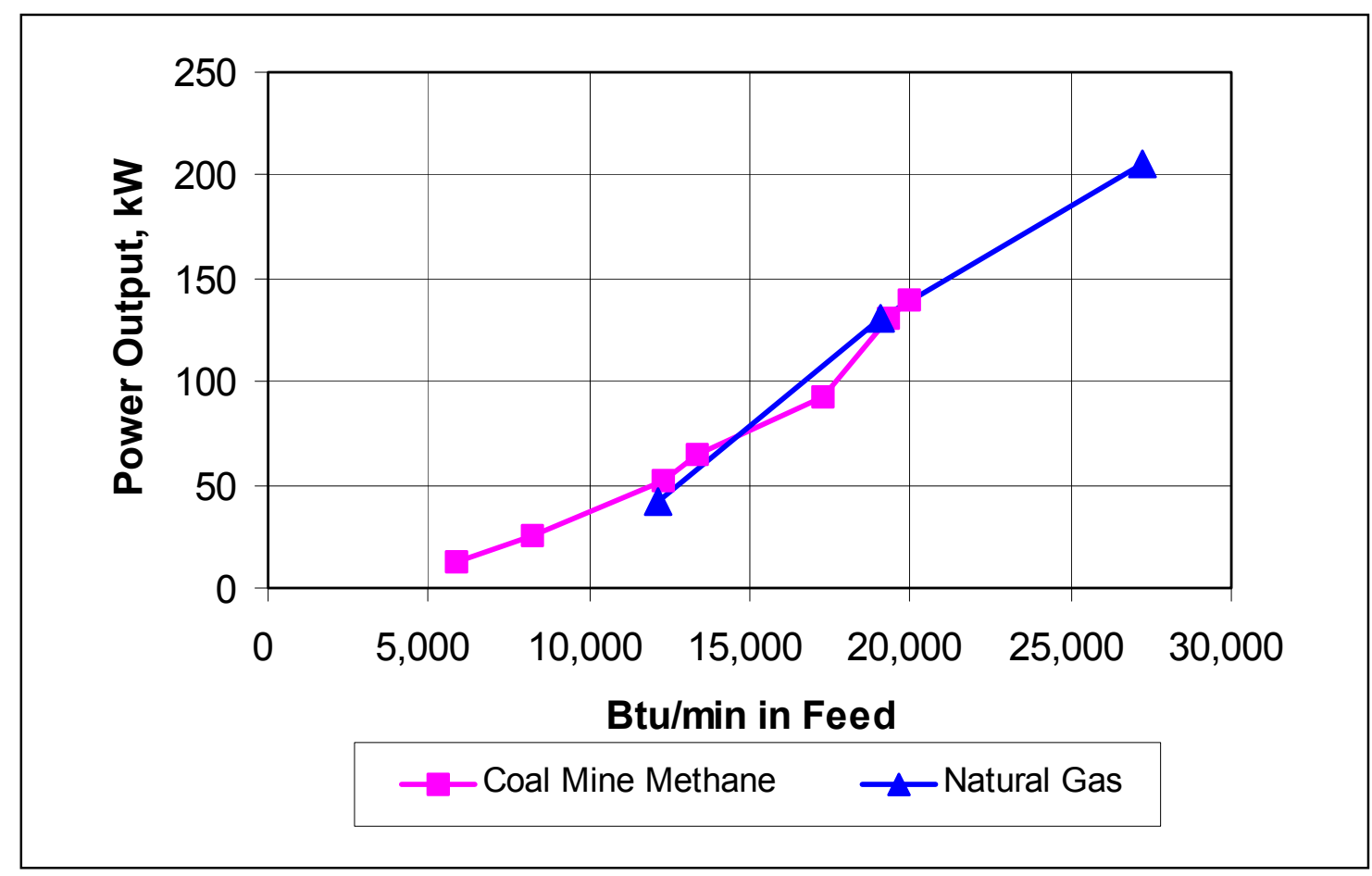

\section{Figure 18. COMPARISON OF POWER OUTPUT FOR CMM OPERATION VS. NATURAL GAS OPERATION:}

Operation on CMM is close to natural gas operation on a Btu feed basis

Although modifications were made to the power plant to accommodate the higher fuel flow necessary for the low BTU coal mine methane gas (based on $72 \%$ methane content originally measured at the Rose Valley test site), testing indicated that flow control was near maximum controllable flow at the 15 psig inlet design pressure at $140 \mathrm{~kW}$ power output. A pressure relief valve on the fuel inlet line was replaced for one that would relieve at a higher pressure. This allowed for up to15 psig pressure operation on coalmine methane compared to 8 psig maximum used for natural gas operations. In addition the fuel mass flow meter was also changed for one with a higher flow range. However, even with these changes, the maximum flow that could pass through the meter and still be within the controllable limits was estimated at $180 \mathrm{~kW}$ power output.

Within the flow range tested no adverse impact of the higher fuel flow rate was observed. It is believed that somewhat higher fuel flows were possible in the configuration tested, and that with improved flow control design sufficient flow can be achieved to achieve near full design power of the power plant.

\section{Environmental Impact}

The environment impact of a fuel cell power plant is significantly lower than conventional power plants as previously shown in Table 5 (Introduction Section). The $\mathrm{CO}_{2}$ emissions shown in Table 12 for coalmine methane are based on operation of the fuel cell power plant tested in this demonstration. The $\mathrm{CO}_{2}$ produced by utilizing coal mine methane $\left(0.57 \mathrm{kgCO}_{2} / \mathrm{kWh}\right.$ is slightly 
above that for natural gas $(0.43 \mathrm{~kg} \mathrm{CO} / \mathrm{kWh})$ due to the $\mathrm{CO}_{2}$ contained in coal mine methane. However it is less than conventional power generation from coal $\left(0.881 \mathrm{~kg} \mathrm{CO}_{2} / \mathrm{kWh}\right)^{(11)}$. In addition, due to the Global Warming Potential of Methane being 23 times $\mathrm{CO}_{2}$ by mass, the net result of CMM utilization by a fuel cell is that it avoids $0.86 \mathrm{~kg} \mathrm{CO} / \mathrm{kWh}$ of electricity produced. This means that for each $\mathrm{kW}$ of electricity produced by the fuel cell, the $\mathrm{CO}_{2}$ emissions produced from an additional $0.98 \mathrm{~kW}(0.86 / 0.881)$ of coal based power generation is avoided.

Table 12. CARBON DIOXIDE EMISSIONS OF A DIRECT FUEL CELL POWER PLANT:

Operation of a DFC fuel cell power plant on CMM is equivalent to avoiding $0.86 \mathrm{~kg} \mathrm{CO} / / \mathrm{kWh}$ produced

\begin{tabular}{|l|l|l|l|l|}
\hline & & & & Notes \\
\hline & $\begin{array}{l}\mathrm{CO}_{2} \text { Produced } \\
\mathrm{kg} / \mathrm{hr}\end{array}$ & $\begin{array}{l}\mathrm{CO}_{2} \text { Produced } \\
\mathrm{kg} \mathrm{CO}_{2} / \mathrm{kWh} \\
\text { electricity }\end{array}$ & $\begin{array}{l}\mathrm{CO}_{2} \text { Displaced } \\
\mathrm{kg} \mathrm{CO}_{2} / \mathrm{kWh} \\
\text { electricity } \\
\text { produced }\end{array}$ & \\
\hline $\begin{array}{l}\text { DFC Power Plant } \\
\text { operating on } \\
\mathrm{CMM}^{(1)}\end{array}$ & $\begin{array}{c}78 \\
(173 \mathrm{lb} / \mathrm{hr})\end{array}$ & $\begin{array}{l}0.56 \\
(1.23 \mathrm{lb} / \mathrm{kWh})\end{array}$ & $\begin{array}{l}0.86 \\
(1.9 \mathrm{lb} / \mathrm{kWh})\end{array}$ & $\begin{array}{l}\text { As tested at } 140 \\
\mathrm{~kW} \text { power }\end{array}$ \\
\hline $\begin{array}{l}\text { DFC Power Plant } \\
\text { Operating on } \\
\text { CMM }\end{array}$ & $\begin{array}{l}140 \\
(308 \mathrm{lb} / \mathrm{hr})\end{array}$ & $\begin{array}{l}0.56 \\
(1.23 \mathrm{lb} \mathrm{CO} / \mathrm{kWh})\end{array}$ & $\begin{array}{l}0.86 \\
(1.9 \mathrm{lb} / \mathrm{kWh})\end{array}$ & $\begin{array}{l}\text { Projected at } 250 \\
\mathrm{~kW} \text { power }\end{array}$ \\
\hline $\begin{array}{l}\text { DFC Power Plant } \\
\text { operating on } \\
\text { Natural Gas }\end{array}$ & $\begin{array}{l}108 \mathrm{~kg} / \mathrm{hr} \\
(238 \mathrm{lb} / \mathrm{hr})\end{array}$ & $\begin{array}{l}0.43 \\
(0.952 \mathrm{lb} \mathrm{CO} / \mathrm{kWh})\end{array}$ & $\begin{array}{l}\text { At 250 kW } \\
\text { power }\end{array}$ \\
\hline
\end{tabular}

(1) Based on CMM tested in Hopedale, Ohio as reported in this report

(2) Assuming conventional coal based power generation is displaced ${ }^{(12)}$

The environmental impact in terms of noise and other emissions from the fuel cell power plant is shown in Table 13. This data is based on natural gas operation and is expected to be similar for coalmine methane operation.

Table 13. ENVIRONMENTAL IMPACT A FUEL CELL POWER PLANT: Fuel Cell Operation results is very low emissions and noise

\begin{tabular}{|l|l|}
\hline Noise & $60 \mathrm{dBA}$ at 10 meters \\
\hline NOx & $<0.1 \mathrm{ppmv}$ \\
\hline SOx & $<0.01 \mathrm{ppmv}$ \\
\hline $\mathrm{CO}$ & $<10 \mathrm{ppmv}$ \\
\hline VOC & $<10 \mathrm{ppmv}$ \\
\hline
\end{tabular}




\section{Power Plant Availability}

Power plant operations experienced six interruptions, including three minor interruptions. Most of these interruptions were related to gas drying/compression and other site related items. Additional detail is provided below.

a. minor interruptions

A blown fuse in the interface supply panel between the power plant and the grid on September 16, 2003 caused the first minor interruption. A gas dryer valve failure on October 25, 2003 and November 4, 2003 was the cause of the remaining minor interruptions in power operations.

\section{b. Other interruptions}

The power interruptions were caused by sequential events. The first interruption was a planned shutdown to replace a leaking bushing in the $69 \mathrm{kV}$ transformer at the Rose Valley site. All power was disconnected to the plant for three days. When the plant was back to operating conditions, two additional dryer valves failed along with a 1/16 HP motor driving an air-cooled after-cooler and moisture separator in the dryer regeneration loop.

A second interruption occurred on November 9, 2003 when the coalmine methane compressor failed. The gas compressor was repaired in two days, however a leak in the water supply valve caused water to flood the pre-reformer resulting in a delayed restart.

The last power interruption was a planned shutdown to replace a leaking pressure relief valve, however on restart the dryer failed followed by the water treatment pump failure. These items were replaced or repaired, however, before power operations could be resumed, a blockage in the site water delivery system occurred. This blockage was due to a frozen water line in the spring water system, as the ambient temperatures were very low. At this point in time we were 1 week away from the planned shutdown of the power plant, and it was decided that a repair could not be completed in time before the planned shutdown. The plant was therefore cooled down for shutdown about 1 week ahead of the planned shutdown.

Figure 19 shows the categories of outages and their fraction of the total down time. Overall, the gas dryer and compressor accounted for the largest (43\%) fraction of down time, followed by the fuel cell balance of plant (BOP) related items (38\%). The site related issues, referring to the power transformer, accounted for the remaining $18 \%$. The calculated availability was $45 \%$ due to the cumulative effects of these factors. 


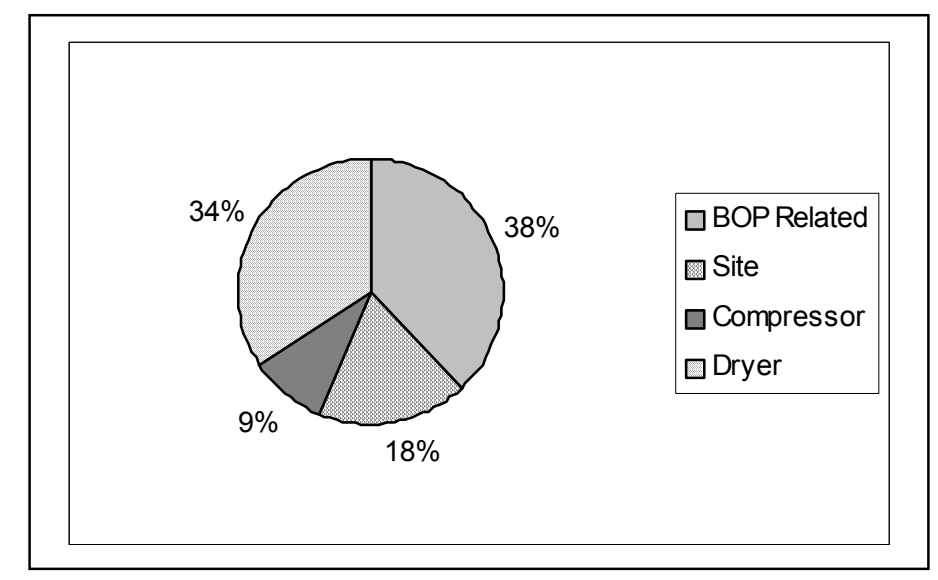

\section{Figure 19. DOWN TIME BREAKDOWN FOR THE FUEL CELL DEMONSTRATION ON COAL MINE METHANE:}

Site related items accounted for most the interruptions

\section{CONCLUSIONS}

The conclusions drawn from this demonstration on coalmine methane are:

1. Operation of the fuel cell in this demonstration test utilized 1,795,556 standard cubic feet (SCF) of $\mathrm{CH}_{4}$ as $\mathrm{CMM}$. This is equivalent to: a) avoiding 725 metric tons of carbon dioxide emissions, b) avoiding 1.6 million pounds of carbon dioxide emissions, c) removing 160 cars off the road for one year, d) heating 26 households for 1 year, e) planting 218 acres of trees. (Reference: U.S. Environmental Protection Agency, Coalbed Methane Outreach Program, http://www.epa.gov/coalbed/resources/converter.html).

2. The direct fuel cell can operate on low-Btu CMM with $\sim 40 \%$ methane content and achieve performance comparable to natural gas on a Btu feed basis.

3. Deoxidation of CMM was effective although low oxygen content was observed in the CMM tested.

4. Variations in CMM flow did not pose problems in the operation of the fuel cell power plant. The plant was monitored on site daily and adjustments were made as needed. It is anticipated that future power plants operating unattended will be programmed for automatic control to handle variations in CMM flow.

5. Utilization of fuel cells to mitigate CMM emissions is an attractive option that can be utilized to generate power at high efficiencies and with very low emissions.

6. Elimination of the need for drying CMM should be explored by using flow measurement methods that are insensitive to moisture.

7. Energy required for compression and drying of coal mine methane should be minimized to maximize overall power plant efficiency. 
8. The economics of power generation utilizing the Direct FuelCell will be driven by the capital cost of the fuel cell and local electricity rates. At current costs, subsidies are required to make the cost of electricity competitive. FCE is currently engaged in an aggressive cost reduction program to reduce capital cost of the fuel cell power plant. It is therefore anticipated that future power plants will produce power at competitive costs utilizing CMM. Future emissions credits will help realize this goal as well.

9. Future operation of a $250 \mathrm{~kW}$ Fuel Cell Power Plant on CMM for one year will utilize $18,400,000$ cubic feet of methane. This will be equivalent to: a) avoiding 7428 metric tons of $\mathrm{CO}_{2}$ emissions, b) avoiding 16.4 million pounds of $\mathrm{CO}_{2}$ emissions, c) removing 1640 cars off the road for one year, d) heating 267 households for 1 year, d) planting 2234 acres of trees. (Reference: U.S. Environmental Protection Agency, Coalbed Methane Outreach Program, http://www.epa.gov/coalbed/resources/converter.html)

Based on the results obtained in this demonstration it can be concluded that utilization of fuel cells to mitigate CMM emissions is an attractive option that can be utilized to generate power at high efficiencies and with very low emissions.

\section{REFERENCES}

1. Inventory of Greenhouse Gas Emissions and Sinks 1990-2001. U.S. Environmental Protection Agency, April 15, 2003, EPA 430-R-03-04

http://yosemite.epa.gov/oar/globalwarming.nsf/content/ResourceCenterPublicationsGHGEmissionsUSEmissionsInventory2003.html

2. Sanderson R., Ghezel-Ayagh H., Steinfeld G., Soot P., and D. Jesse, Utilizing Fuel Cells to Generate Power from Coal Mine Methane, Phase II Final Report, Volume 1, Summary of Phase I and Phase II, Prepared for U.S. Department of Energy, Federal Energy Technology Center under contract DE- $\backslash$ AC21-95MC32189, October 29, 1999, by FuelCell Energy

3. Soot, P, Northwest Fuel Development Inc. December 31, 2001. Data obtained by detector tubes.

4. Northwest Fuel Development Inc, Utilizing Fuel Cells to Generate Power from Coal Mine Methane, Phase II Final Report, Volume 2, Task 3 Market Potential, International Fuel Cell Market Fueled with Waste Methane from Coal Mines, Prepared for Charles Byrer, U.S. Department of Energy, Federal Energy Technology Center, Morgantown, WV. Submitted by Fuel Cell Energy Inc. under contract DE-AC21-95MC32189, Oct 29, 1999

5. Sanderson R., Steinfeld G., Utilizing Fuel Cells to Generate Power from Coal Mine Methane. Task 4 Topical Report, Evaluation Study and Conceptual Design. Prepared for U.S. Department of Energy, Federal Energy Technology Center, Under Contract DE-AC2195MC32189, October 29, 1999, by FuelCell Energy.

6. Valenti, M., New Avenues for Electrochemistry, Feature Focus: Fuel Cells. Fuel cell systems are being designed for service at coalmines, private homes, and tomorrow's battlefields. Mechanical Engineering, February 2001. 
7. Steinfeld G., Sanderson R., Soot P. and D.R. Jesse, Utilizing Fuel Cells to Generate Power from coal mine methane, presented at the North American Coalbed Methane Forum, April 21, 1997, Marriott Pittsburgh Airport.

8. Steinfeld G. and Jacobsen M. Direct FuelCell Applications to reducing Mine Methane Emissions, Presented by M. Jacobsen at the BCC Fuel Cells 2001 Conference, April 1-3, 2001, San Antonio, TX.

9. Hunt J., $250 \mathrm{~kW}$ Fuel Cell Demonstration Using Coal Mine Methane, Presented at the North American Coalbed Methane Forum, Washington, PA, April 26, 2001

10. Bibler C. and Carothers, P. Overview of Coal Mine Gas Use Technologies, $2^{\text {nd }}$ International Methane Mitigation Conference, Novosibirsk, Russia, June 2000.

11. U.S. Environmental Protection Agency, Coalbed Methane Outreach Program, http://www.epa.gov/coalbed/resources/converter.html.

12. Association of Coal Mine Methane Operators (UK)

http://www.acmmo.org/CO2emissions.doc 


\section{LIST OF ACRONYMS}

$\begin{array}{ll}\text { AEP } & \text { American Electric Power } \\ \text { BOP } & \text { Balance of Plant } \\ \text { CMM } & \text { Coal Mine Methane } \\ \text { COE } & \text { Cost of Electricity } \\ \text { DFC } & \text { Direct FuelCell } \\ \text { DI } & \text { Deionized } \\ \text { DOE } & \text { Department of Energy } \\ \text { EBOP } & \text { Electrical Balance of Plant } \\ \text { EDI } & \text { Electrodeionization } \\ \text { EPA } & \text { Environmental Protection Agency } \\ \text { FCE } & \text { FuelCell Energy } \\ \text { GC } & \text { Gas Chromatograph } \\ \text { GPM } & \text { Gallons Per Minute } \\ \text { GWP } & \text { Global Warming Potential } \\ \text { HMI } & \text { Human Machine Interface } \\ \text { HP } & \text { Horsepower } \\ \text { IC } & \text { Internal Combustion } \\ \text { IPCC } & \text { Intergovernmental Panel on Climate Change } \\ \text { kV } & \text { Kilovolt } \\ \text { kW } & \text { Kilowatt } \\ \text { kWh } & \text { Kilowatt Hour } \\ \text { LHV } & \text { Low Heating Value } \\ \text { MBOP } & \text { Mechanical Balance of Plant } \\ \text { MCFD } & \text { Thousand Cubic Feet per Day } \\ \text { MTU } & \text { MTU-Friedrichshafen GmbH } \\ \text { MW } & \text { Megawatt } \\ \text { MWh } & \text { Megawatt hours } \\ \text { NETL } & \text { National Energy Technology Laboratory } \\ \text { OAC } & \text { Ohio Administrative Code } \\ \text { RO } & \text { Reverse Osmosis } \\ \text { SCFM } & \text { Standard Cubic Feet per Minute } \\ \text { SCF } & \text { Standard Cubic Feet } \\ & \end{array}$

